\title{
Osmanlı Kroniklerinde Sokollu Mehmed Paşa ve Sokoloviç Ailesi
}

\author{
Sokollu Mehmed Pasha and Sokolovic Family in the Ottoman Chronicles
}

\begin{abstract}
Abdullah ZARARSIZ*
$\ddot{O}_{z:}$ Osmanlı Devleti'nde kuruluş devrinden başlayarak birçok ailenin, devlete önemli katkılar sağladığı bilinmektedir. 16. yüzyılda Sokoloviç ailesi, hem çok sayıda üyesinin devlet hizmetinde görev alması hem de en önemli makamlarda bulunmuş olmalarından dolayı dikkat çekmektedir. Özellikle Sokollu Mehmed Paşa'nın himayesiyle birçok aile üyesi, devlette üst kademelere kadar yükselmeyi başarmıştır. Osmanlı hizmetinde bilinen ilk Sokoloviç olan Deli Hüsrev Paşa'nın yanı sıra, Hüsrev Paşa'nın kardeşi Lala Mustafa Paşa, Sokollu Mehmed Paşa'nın oğlu Hasan Paşa, aile mensuplarından Lala Mehmed Paşa, Mustafa Paşa, Ferhad Paşa gibi devlet adamları, Avusturya ve İran'a yönelik seferlerde oldukça önemli hizmetlerde bulunmuşlardır. Sokoloviç ailesi üyelerinin etkinliği, özellikle Sokollu Mehmed Paşa'nın sadrazamlığı sırasında artmış ve önemli mevkilere getirilmişlerdir. Bu çalışmada, Osmanlı kroniklerinde Sokollu Mehmed Paşa ve Sokoloviç ailesinin diğer üyeleri hakkında verilen bilgiler değerlendirilecek ve aile üyelerinin devlet hizmetindeki faaliyetleri incelenecektir.
\end{abstract}

Anahtar sözcükler: Sokollu Mehmed Paşa, Lala Mustafa Paşa, Lala Mehmed Paşa, Sokoloviç, Bosna

\begin{abstract}
It is known fact that various families made significant contributions to the state, starting from the establishment period of the Ottoman State. The Sokolovic family draws attention in the 16th century. The reason for this is that many of its members have served in the state service and have held the most important positions. In particular, with the patronage of Sokollu Mehmed Pasha, various members of the family managed to rise to the upper ranks in the state. In addition to Deli Hüsrev Pasha, the first Sokolovic known in Ottoman service, statesmen such as Sokollu Mehmed Pasha, Hüsrev Pasha's brother Lala Mustafa Pasha, Sokollu Mehmed Pasha's son Hasan Pasha, family members Lala Mehmed Pasha, Mustafa Pasha, Ferhad Pasha performed very important services in military expeditions to Austria and Iran. Effectiveness of the members of the Sokolovic family increased during the grand viziership of Sokollu Mehmed Pasha and they were appointed to significant administrative positions. In this study, the information in Ottoman chronicles about Sokollu Mehmed Pasha and other members of the Sokolovic family is evaluated and the activities of family members within the state service are examined.
\end{abstract}

Keywords: Sokollu Mehmed Pasha, Lala Mustafa Pasha, Lala Mehmed Pasha, Sokolovic, Bosnia

\section{Giriş}

Osmanlı Devleti, kurulduğu ilk zamanlarda özellikle Bizans sınırında gaziler ve nökerlerin hizmetlerinden faydalanmıştır. Beyliğin yönetim merkezinde bu dönemde Türkmen kökenli ailelerin etkili olduğu bilinmektedir. Kuruluş döneminde Osmanlı Devleti'ne en önemli hizmetleri Çandarlı ailesi vermiştir. Osman Gazi döneminden başlayarak İstanbul'un fethinden sonra Halil Paşa'nın idam edilmesine dek Osmanlı hizmetinde en üst makamda bulunan bu aile,

\footnotetext{
* Arş. Gör. Akdeniz Üniversitesi, Edebiyat Fakültesi, Tarih Bölümü, Antalya, abdullahzararsiz@akdeniz.edu.tr, https://orcid.org/0000-0002-2071-513X
} 
becerikli devlet adamlarıyla Osmanlı Devleti'nin kurumsallaşmasında etkili olmuştur (Çandarlı ailesiyle ilgili bkz. Uzunçarş1lı, 1988). Ancak İstanbul'un fethinin ardından Çandarlı Halil Paşa'nın idam edilmesiyle birlikte devlet yönetiminde Türkmen kökenli devlet adamlarının hegemonyası sona ermiş ve devşirmelerin öne çıktığı bir dönem başlamıştır. Devşirme kökenli devlet adamlarının, aile üyelerini devletin en üst kademelerine getirmesi bu dönemde mümkün olmamıştır. Bunun tek istisnası 16. yüzyılda görülmektedir. Bu yüzyılda Osmanlı Devleti'ne önemli hizmetlerde bulunan ailelerden birisi de Bosnalı Sokoloviç ailesidir. Henüz II. Bayezid saltanatında, yüzyıl boyunca devlete adeta damgasını vuracak olan bu ailenin ilk üyesi, Hüsrev Paşa devşirilerek devlet hizmetine alınmıştır. İşte Bosna'da dünyaya gelen ve hizip çatışmalarının yoğunluğu arasında, üç ayrı padişah döneminde on dört yıl gibi uzun bir süre sadrazamlık yapan Sokollu Mehmed Paşa da bahsi geçen Sokoloviç ailesine mensuptur. Bu çalışmada, Sokollu Mehmed Paşa ve Sokoloviç ailesine mensup olup Osmanlı hizmetinde bulunan diğer devlet adamlarıyla ilgili kroniklerde yer alan bilgilere dair değerlendirmelerde bulunulacaktır. Kroniklerden elde edilen bilgiler ikincil kaynaklardan da desteklenecek ve Osmanlı hizmetindeki Sokoloviçler hakkında bilgiler ortaya konulacaktır.

Ele aldığımız konunun başlıca kaynakları, Sokoloviç ailesi üyelerinin maiyetinde bulunan ve dolayısıyla en yakın kaynaklar olarak kabul edebileceğimiz müelliflerden Selanikî Mustafa Efendi'nin, Gelibolulu Mustafa Âlî Efendi'nin ve Peçevî İbrahim Efendi'nin eserleridir. Söz konusu müelliflerden Mustafa Efendi'nin hayatına dair bilgiler oldukça yetersiz olup eserinde aktardığı bazı ayrıntılar sayesinde Selanikli olduğu ve babasının da Selanik'te vefat ettiği anlaşımaktadır. Müellif, Kanuni Sultan Süleyman'ın son seferi olan Sigetvar kuşatmasına iştirak etmiş ancak bu seferde hangi görevde bulunduğuna dair bir bilgi vermemiştir. 1600 yılında öldüğü tahmin edilen Mustafa Efendi, çeşitli kademelerde görev yapmış, bu sayede devlet işleyişindeki aksaklıkları yakından müşahede etmiştir. 1563 yılından 1600 yılına kadar olan olayları kaydettiği eserinde, yaşadığı dönemin olaylarını aktaran müellif, devletin iktisadi ve idari bakımdan aksayan yönleriyle ilgili eleştirilerde bulunmuştur. Tarih-i Selaniki, 1565'te sadrazam olan Sokollu Mehmed Paşa iktidarının tamamını kapsaması ve dönemin olaylarını bizzat şahit olarak aktarması bakımından önem taşımaktadır (Selanikî 1999, XIV-XXI).

1541 y1lında Gelibolu'da doğan Mustafa Âlî’nin 1560 yılında Şehzade Selim'in (II. Selim) maiyetinde katip olduğu bilinmektedir. Kendisinin de Boşnak kökenli bir aileden geldiği tahmin edilen Âlî, 1562'de Sokoloviç ailesinden Lala Mustafa Paşa'nın davetiyle onun divan katibi olarak önce Haleb'e, sonra Şam'a gitmiş ve altı yıl bu hizmette kalmıştır. Mustafa Paşa'nın Yemen seferine serdar tayin edilmesinden sonra onunla gittiği Mısır'da kısa süre kalan ve ardından İstanbul'a dönen Âlî, 1570'te Sokollu Mehmed Paşa'ya ithaf ettiği Heft Meclis isimli eserine mükafat olarak bir başka Sokoloviç ailesi mensubu Klis sancakbeyi Ferhad Bey'in (daha sonra Paşa) divan katipliğine tayin edilmiştir. Sekiz yıla yakın bir süre Bosna'da kalan müellif, Lala Mustafa Paşa'nın serdarı olduğu Gürcistan ve Şirvan seferine divan katibi olarak katılmıştır. 1580 yılında hamisi Lala Mustafa Paşa'nın vefatından sonra çok istediği nişancılığı elde edemese de çeşitli eyaletlerde defterdarlık görevlerinde bulunan Âlî, 1599 yılında vefat etmiştir. 1593-99 yılları arasında kaleme aldığı en önemli eseri Künhü'l-Ahbar, genel bir dünya tarihi olup dört rükünden oluşmaktadır. Eserin dördüncü rüknü, Osmanlı hanedanının tarihini anlatmaktadır. Pek çok kaynağı tahlil ederek kaleme almış olduğu bu bölüm, kuruluştan başlayarak III. Mehmed saltanatına dek gelmektedir. Âlî’nin bu eseri, hem Sokollu Mehmed Paşa iktidarının tamamını içermesi, hem de Sokoloviç ailesinin diğer üyelerinin hizmetinde bulunması ve yakından edindiği gözlemlerini aktarması bakımından oldukça önemlidir. (İsen 1988, 1-13; Kütükoğlu 1989, 414415; Babinger 1992, 141-143; Âlî’nin hayatı ve tarihçiliği hakkında daha detaylı bilgi için bkz. Fleischer 1996). 
1574 yılında Macaristan'ın Pecs şehrinde dünyaya gelen Peçuyî/Peçevî İbrahim Efendi'nin annesi, Sokoloviç ailesinden Ferhad Bey/Paşa'nın kardeşi olup bu suretle kendisi de Sokoloviç ailesine mensuptur. Uzun süre Bosna ve Macaristan'da kalan İbrahim Efendi, Sokoloviç ailesi mensuplarından hem Ferhad Paşa'nın hem de Lala Mehmed Paşa'nın maiyetinde bulunmuştur. Lala Mehmed Paşa'nın 1606 yılındaki ölümünün ardından il yazıcılığı, defterdarlık, sancakbeyliği gibi çeşitli görevlerde bulunan İbrahim Efendi, 1641 yılında azledilmiş ve ömrünün son yıllarını eserini yazmakla geçirmiştir. 1649 yılı civarında vefat ettiği düşünülen müellifin kaleme almış olduğu Tarih, Kanuni Sultan Süleyman'ın tahta çıktığı 1520 yılında başlamakta ve 1640 yılında sona ermektedir. Eserini yazarken Osmanlı kaynaklarının yanı sıra Macar kaynaklarını da kullanan İbrahim Efendi'nin Tarih'i, Sokoloviç'lere dair en ayrıntılı bilgileri içermesi açısından önem taşımaktadır (Turan 1964, 543-545; Hancz 2007, 216-218).

Yukarıda sayılan eserlerin yanı sıra, içeriği Kanuni Sultan Süleyman'dan başlayarak III. Murad'ın ölümüne kadar olan olayları kapsayan Hasan Beyzade Ahmed Paşa'nın Tarih'i de kaynaklar arasında bulunmaktadır. Reisülküttab Hasan Bey'in oğlu olması nedeniyle Hasan Beyzade olarak anılan Ahmed Bey, küçük yaşlarda Divan-1 Hümayun hizmetine girmiş ve 1593 'te başlayan Avusturya harplerinde pek çok cephede savaşa katılmıştır. 1605 yılında defter emini olan Ahmed Bey daha sonra maliye hizmetine geçerek farklı eyaletlerde defterdarlık görevini ifa etmiştir. 1610 yılından sonra Kefe beylerbeyliğine tayin edilmiş olsa da kısa süre sonra bu görevden azledilen Ahmed Bey'in bundan sonraki kariyeri defterdar olarak hizmetle geçmiş, 1635 yılında IV. Murad'ın Revan seferine katılmış ve bu seferden döndükten kısa bir süre sonra vefat etmiştir. Ahmed Paşa'nın kaleme almış olduğu Tarih, iki bölümden oluşmaktadır. İlk bölümü Hoca Sadeddin Efendi'nin Tacü't-tevarih'inin kısa özet şeklinde olan bu eserin kıymet taşıyan kısmı ise Kanuni Sultan Süleyman saltanatından başlayıp IV. Murad devrinin büyük bölümünü içeren ikinci bölümüdür. Kanuni devri olaylarını büyük oranda kendinden önceki tarihleri kaynak kullanarak kaleme alan Hasan Beyzade, III. Mehmed devrinden itibaren bizzat şahit olduğu olayları neden-sonuç ilişkisi içinde aktarmıştır (Baysun 1953, 321-340; Aykut 1997, 363-364). Konuya dair temel kaynaklarımızı adı geçen kronikler oluşturmakta, bu dönemden sonra kaleme alınan kronikler genellikle bu kroniklerde kaydedilen bilgilerin tekrarı niteliğinde olduğu için yeri geldiğinde dönemle ilgili bilgi ve yorumlar içeren diğer kroniklere de başvurulmuştur.

\section{Divane (Deli) Hüsrev Paşa}

1495 yılından önce doğduğu tahmin edilen ve Sokoloviç ailesinden devşirilen ilk kişi olan Hüsrev Paşa, Enderun' da yetiştikten sonra süvari bölüklerine geçmiş, işlediği bir suç yüzünden saraydan uzaklaştırılmıştır. Daha sonra bazı vezirlerin aracılığı ile affedilerek saraya gelen Hüsrev Paşa çaşnigirbaşılık, kapıcılar kethüdalığ 1 , mirahurluk görevlerinde bulunmuştur. I. Selim'in emrinde Çaldıran seferine katılan Hüsrev Paşa, 1514 yılında Karaman beylerbeyi olmuş, 1516' da Harput'u ele geçirdikten sonra Mısır seferine katılmıştır. 1521 yılında Anadolu beylerbeyliğine getirilen Hüsrev Paşa, aynı yılın sonlarında Diyarbekir beylerbeyliğine getirilmiştir (Özcan 1999, cilt XIX, 40). 1526 yılında Diyarbakır beylerbeyi iken Bozok civarında çıkan Celalî ayaklanmalarının bastırılmasında görev alan (Celalzade 2011, 131) ve 1531 yılına kadar Diyarbekir'de kalan Hüsrev Paşa, bu görevi boyunca pek çok suçlamayla karşı karşıya kalmış ve Safevi Devleti'nin valisi iken Osmanlı Devleti'ne sığınan Ulama Paşa ile arasının açılmasının da etkisiyle azledilerek İstanbul'a dönmüştür. Bir süre sonra Anadolu beylerbeyliğine getirilen Hüsrev Paşa, 1532 yılında Sultan Süleyman'la birlikte Alman seferine katılmış, (Celalzade 2011, 176) seferin dönüşünde Haleb (Mehmed Süreyya 1996, cilt II, 684), ardından 1534'te Şam beylerbeyliğine tayin edilmiş ve Irakeyn seferine iştirak etmiştir. Bu seferin ardından Mısır beylerbeyliğine getirilen (Lütfi Paşa 
1341, 351; Nasûhü's-Silâhî (Matrakçı) 1976, 238) ve iki yıla yakın burada kalan Hüsrev Paşa, görevden azledildikten sonra İstanbul'a dönmüştür. Peçevî, 1538 yılında Hüsrev Paşa'nın Anadolu beylerbeyi olduğunu belirtmiş̧ir. Ancak Boğdan seferine çıkılmadan önce vezir Mustafa Paşa vefat edince divan silsilesinde değişiklik yapılmış ve Hüsrev Paşa'ya Rumili beylerbeyliği tevcih edilmiştir. Aynı tevcihatta Rüstem Paşa da Anadolu beylerbeyi olmuştur (Peçevî 1866, cilt I, 206; Künhü'l-Ahbar'ın Osmanlı tarihini içeren dördüncü rüknünün II. Selim, III. Murad ve III. Mehmed dönemlerine dair olan kısmı Faris Çerçi tarafından transkribe edilerek yayınlanmıştır. Âlî 2000, cilt I-II-III; Âlî 2009, cilt I, vr.308a; Celalzade 2011, 227-228).

Hüsrev Paşa, Sultan Süleyman'la birlikte Boğdan seferine katılmış, ardından Budin'in savunmasında görev almıştır. Verilen görevleri başarıyla yerine getiren Hüsrev Paşa, Sultan Süleyman tarafindan 1541 yılında dördüncü vezirliğe getirilmiş ve 1543 'te Estergon ve İstolni Belgrad'in fethedildiği sefere iştirak etmiştir (Özcan 1999, cilt XIX, 40-41). Peçevî, Hüsrev Paşa'nın Mısır beylerbeyliğinden dönüşünde ikinci vezirliğe getirildiğini kaydetmişse de Hüsrev Paşa'nın bu dönemde tekrar Mısır'a tayin edildiğine dair açık bilgi yoktur. Âlî’ye göre o dönemde sadrazam Süleyman Paşa, ikinci vezir Hüsrev Paşa ve üçüncü vezir de Rüstem Paşa'dır. Bu iki güçlü rakibinden kurtulmadan sadrazam olamayacağını düşünen Rüstem Paşa, araları zaten açık olan iki paşayı birbirine düşürmüştür. Bir gün divanda Hüsrev Paşa hançer ile Süleyman Paşa'nın üzerine yürümüş ve Rüstem Paşa buna engel olmuştur. Sultan Süleyman, bu tatsız olay1 öğrenince iki paşa da vezirlikten azledilmiş ve Rüstem Paşa sadrazam olmuştur (Peçevî 1866, cilt I, 29; Âlî, 2009, cilt I, vr.362b).

Vezirlikten azledilmesine oldukça içerleyen Hüsrev Paşa, eski saygınlığını kaybetmenin üzüntüsüyle vesveseye kapılmış ve kapı halkından bile şüphelenir hale gelmiştir. Adamlarının kendisini zehirleyeceğinden şüphelenen Hüsrev Paşa, on yedi gün yemeden içmeden kesilmiş ve vefat etmiş (Lütfi Paşa 1341, 434), İstanbul'da Fatih Yenibahçe'de yaptırdığı türbesine defnedilmiştir (Özcan 1999, cilt XIX, 41).

\section{Sokollu Mehmed Paşa}

1505 yılında Bosna'nın Vişegrad kazasının Rudo nahiyesinde bulunan Sokolovići köyünde dünyaya gelen (Gökbilgin 1979a, cilt VIII, 595; Ahmed Refik 2017, 7) ve Osmanlı kroniklerinde uzun boyuna atfen "Tavil (Uzun)", suikast sonucu öldürülmesi nedeniyle de "Şehid" olarak anılan Mehmed Paşa'nın çocukluğuna ilişkin Osmanlı kronikleri oldukça suskun kalmaktadır. Dönemi anlatan müelliflerden yalnızca Peçevî İbrahim Efendi, Paşa'nın ailesi ve devşirilmesi hakkında bilgi vermektedir. Ancak bu hususta yalnızca Sokollu'nun Bosna'da Sokoloviç, yani Şahinoğulları neslinden olduğunu belirtmekte, etnik mensubiyeti hakkında ise hiçbir bilgi vermemektedir. Bununla birlikte yine aynı aileye mensup Lala Kara Mustafa Paşa için kullandığ 1 "Bosneviyyü'lasl Sokoloviç nâm nesl-i ma "rûfdandır" tabiri, ailenin Boşnak asıllı olduğunu işaret etmektedir (Peçevî 1866, cilt I, 24-25). Mustafa Âlî de hem Mehmed Paşa'nın hem de Lala Mustafa Paşa'nın "Bosnevî" olduğunu vurgulamaktadır (Âlî 2009, cilt I, vr.451b, vr.482b). Yine Âlî’nin, Sokollu Ferhad Paşa'nın öldürülmesini ima eden Sinan Paşa'nın sarf ettiğini kaydettiği "beylerbeyiniz olan Potur sağ mıdır?" ifadesi de ailenin Boşnak kökenli olduğunu düşündürmektedir (Âlî 2009, cilt I, vr.551a; Potur kelimesi, Bosna Müslümanlarını ifade etmek için kullanılan bir tabirdir. Potur teriminin kökeni ve Bosna'nın İslamlaşma sürecine dair detaylı bilgi için bkz. Koyuncu 2015, 213-259). Tarih-i Bosna ve Hersek isimli eserin müellifi Muvakkit Salih Sidk1 Efendi, Sokoloviç ailesinden olan Budin beylerbeyi Mustafa Paşa'nın "Boşnak" olduğunu belirtmektedir (Muvakkit Salih Sıdkı Efendi?, cilt I, 330). Rumen tarihçi Jorga da Sokollu Mehmed Paşa'nın Boşnak asıllı olduğunu kabul etmektedir (Jorga 2005, cilt III, 116). Sırp tarihçi Samarcic, Sokoloviç'lerin Sırp asıllı olduklarını, Mehmed Paşa'nın doğduğunda Bayo ismini aldığını ve 
Mileseva'da bir manastırda rahiplik yapan dayısının yanında bulunurken Yeşilce Mehmed Bey tarafından devşirildiğini kaydetmiştir (Samarcic 1995, 8-10). Mustafa Selanikî Efendi ise ailenin Hırvat asıllı olduğunu işaret etmiştir (“... bu saltanat veziri, Hırvat içinde namdar Sokolovikoğlu...” Selanikî 1999, 33). Zinkeisen ise Sokollu'nun Dubrovnik yakınlarındaki Trebinye'de doğduğunu belirtmiş ancak etnisiteye dair herhangi bir şey söylememiştir (Zinkeisen 2011, cilt III, 66). Bütün bu kayıtlar değerlendirildiğinde hem Peçevî’nin hem de Âlî’nin kullandığı "Bosnevî" tabirinin coğrafyadan ziyade etnisiteyi belirtmek amacıyla kullanıldığ 1 ve Sokoloviç ailesinin Boşnak asıllı olduğu düşünülebilir.

1520'li yılların başında Sokolovići köyüne devşirme yazıcısı olarak gelen yayabaşı Yeşilce Mehmed Bey (divan katipliği, başdefterdarlık, reisülküttaplık gibi görevlerde bulunan Mehmed Bey, 1557'de nişancılığa getirilmiş, daha sonra Mısır valisi olmuştur. Kanuni Sultan Süleyman'ın isteğiyle Tarih-i Ramazanzade ya da Tarih-i Nişancı adıyla bilinen eserini yazmış, bu eserde kısa bir dünya tarihinin ardından Osman Gazi döneminden başlayarak 1561 yılına kadar gelen olayları anlatmıştır. Yeşilce lakabıyla da anılan Mehmed Paşa 1571'de vefat etmiştir. Babinger 1992, 115; Afyoncu 2009a, cilt XXXVII, 354), köyün ünlü ailesinin büyük oğlunu da devşirme olarak yazmak istemiştir. Ailenin itirazları ve Mehmed Bey'e rüşvet dahi teklif edilmesi fayda etmemiş ve sonuçta bu çocuğun da dâhil olduğu kırk kadar çocuk Edirne'de bulunan Sultan Süleyman'ın huzuruna gönderilmiştir (Ahmed Refik 2017, 8; Nahîfî Mehmed Efendi 2019, 142-148).

\section{Sultan Süleyman ve Sokollu Mehmed Paşa}

Devşirildikten sonra Mehmed adını alan bu çocuk, Edirne sarayında bir süre eğitim almış ve daha sonra İstanbul'a, Yeni Saray'a gönderilmiştir. Burada küçük odalardaki hizmetinde başarı gösteren Mehmed Ağa, daha sonra Sultan Süleyman tarafından iç hazineye alınmıştır. Burada da görevlerini layıkıyla yerine getiren Mehmed Ağa sarayda rikabdarlık (eyerin üzengisini tutarak padişahın ata binip inmesine yardımcı olan görevli), çukadarlık (padişahın kaftan ve kürklerine bakmakla yükümlü olan görevli) ve silahdarlık (padişahın silahlarını taşımakla yükümlü görevli), çaşnigirbaşılık (sultanın yiyeceği yemeği, içinde zehir olup olmadığını anlamak için ondan önce tatmakla yükümlü görevli) ve kapıcılar kethüdalığ1 (sarayın babüssaade dışındaki bütün kapılarında bekleyen kapıcıların amiri durumundaki görevli) gibi görevlerde bulunmuştur (Abdurrahman Şeref 1330, cilt V, 261; Nahîfî Mehmed Efendi 2019, 148). Sarayda kendi yerini sağlama alan Mehmed Ağa, silahdarlık yaparken ailesini de İstanbul'a getirtmek istemiş ve bu amaçla Bosna haracını toplamak için oraya hareket etmek üzere olan Ahmed Bey'den kardeşlerini de İstanbul'a getirmesini rica etmiştir. Ahmed Bey, Mehmed Ağa'nın ailesini bulmuş ve isteğini iletmiştir. Fakat annesinin bu isteği kabul etmemesi üzerine bir ara formül bulunmuştur. Buna göre babası, Ağa'nın ortanca kardeşini de alarak İstanbul'a gitmiş, küçük kardeş ise annesinin yanında kalmıştır. Mehmed'in kardeşine çok benzeyen amcazadesi de küçük kardeşin yerine geçerek İstanbul'a gelmiştir (Sokollu Mehmed Paşa'nın vakfiyesine göre babası Müslüman olduktan sonra Cemaleddin Sinan adını almıştır. Gökbilgin 1979a, cilt VIII, 595; Ahmed Refik 2017, 9-11; Nahîfî Mehmed Efendi 2019, 151-156).

Mehmed Ağa, İstanbul'a gelen kardeşlerini Sultan Süleyman'ın huzuruna çıkarmış ve kardeşler padişahın emriyle eğitim almak üzere Galata Sarayı'na gönderilmişlerdir. Ortanca kardeşine Mustafa ismi konmuş, fakat kısa bir süre sonra vefat edince bu sefer küçük kardeşi olarak gelen amcazadesine Mustafa ismi verilmiştir. Mustafa da Mehmed Ağa gibi görevlerini eksiksiz yapmış ve göze girmeyi başarmıştır. Bir süre sonra Mustafa'nın Mehmed Ağa'nın kardeşi olmadığını kabul etmesi üzerine Mehmed Ağa küçük kardeşini de İstanbul'a getirtmiş ve fakat o da vefat etmiştir (Ahmed Refik 2017, 12-14). 
Aslında Sokoloviç ailesinden devşirilen ilk çocuk Mehmed Paşa değildir. Mehmed Paşa'dan yaklaşık yirmi yıl önce devşirilen ve beylerbeyliğe kadar yükselen Lala Kara Mustafa Paşa'nın ağabeyi Hüsrev Paşa da Sokoloviç ailesine mensuptur (Peçevî 1866, cilt II, 20). Devşirilen ilk Sokoloviç Hüsrev Ağa bir süre sonra kardeşini de İstanbul'a getirtmiş ve o da Mustafa adını almıştır. Bundan sonra Mehmed Ağa'nın amcazadeleri olan Ferhad, Ali, Derviş ve Mehmed Beyler de İstanbul'a gelerek devlet hizmetine girmiş ve böylece Sokoloviç ailesinin İstanbul'daki mensuplarının sayısı artmıştır (Ahmed Refik 2017, 14).

Padişahın hizmetkârı olması dolayısıyla bütün seferlerinde yanında bulunan Mehmed Ağa'nın hayatı hakkında, kapudan-1 derya olarak tayin edilişine kadar sarih bilgiler yoktur. Ancak 1526 Mohaç seferine, 1529 Viyana seferine katıldığına dair rivayetler bulunmaktadır. Daha sonra defterdar İskender Çelebi'nin maiyetine katılan Mehmed Ağa, onunla birlikte 1533-35 İran ve Bağdad seferlerine iştirak etmiştir. Ancak İskender Çelebi, bu seferde sadrazam İbrahim Paşa (Makbul, Maktul) ile arasındaki anlaşmazlık üzerine bilvesile idam edilmiş ve aralarında Sokollu Mehmed Paşa ile Lala Mustafa Paşa'nın da bulunduğu maiyeti saraya gönderilmiştir (Samarcic 1995, 17-18; Âlî 2009, cilt I, vr.303a).

$\mathrm{Bu}$ tarihten sonra Mehmed Ağa sarayda çeşitli hizmetlerde bulunmuştur. Mehmed Ağa'nın saraydan taşra çıkması ise 1546 yılında olmuştur. Barbaros Hayreddin Paşa'nın 5 Temmuz 1546 tarihinde (Ahmed Cevdet Paşa 2018, cilt I, 153) ölmesi üzerine o dönemde kapıcılar kethüdası olan Mehmed Ağa, kapudan-1 derya olarak tayin edilmiştir (Abdurrahman Şeref 1330, cilt V, 261; Uzunçarşılı, Peçevî' den naklen anlattığı 1541 yılı olaylarında, Avusturya arşidükü Ferdinand'ın Budin'i kuşatması üzerine üçüncü vezir Sokollu Mehmed Paşa'nın üç bin yeniçeri ve bölük ağalarıyla Budin'e gönderildiğini kaydetmiştir. Ancak Peçevî'nin bu dönemin olaylarını anlatırken bahsettiği üçüncü vezir Mehmed Paşa'yı Sokollu Mehmed Paşa ile karıştırarak Sokollu Mehmed Paşa'nın henüz taşra çıkmadan Rumili beylerbeyi olması gibi bir hataya düşmüştür. Peçevî 1866, cilt I, 226; Uzunçarş11ı 2011, cilt II, 338). Görevde olduğu sürede çok sayıda gemiyi Osmanlı donanmasının hizmetine sokan (Avrupalı görevlilerin raporuna göre bu dönemde Haliç'in Beyoğlu kıyısında yaptırılan yeni tersanede üç yüze yakın işçi çalışıyor, bir kadırganın yapımı biter bitmez yenisinin yapımına başlanıyordu. Samarcic 1995, 24) Mehmed Paşa'nın kapudan-1 deryalığı uzun ömürlü olmamıştır. Kısa süre sonra 1549 yılında Rumili beylerbeyliğine atanan Paşa, bu görevinde Avusturya'ya karşı önemli faaliyetlerde bulunmuştur. 1551 yılında Avusturya Arşidükü Ferdinand'ın Erdel'e saldırması üzerine harekete geçen Mehmed Paşa, Baç, Beçkerek, Çanad, Varat ve Lipova kalelerini ele geçirmiştir (Peçevî 1866, cilt I, 285-287; Hammer 1332, cilt VI, 17; Âlî 2009, cilt I, vr.320b-322b). 1552'de Tımışvar'ın fethinde önemli hizmetleri olan Paşa, Eğri kuşatmasına da katılmıştır (Hammer 1332, cilt VI, 32). Şehzade Mustafa'nın öldürüldüğü Sultan Süleyman'ın İran seferine de iştirak etmiş ve bu seferde gösterdiği başarıdan ötürü vezaretle ödüllendirilerek üçüncü vezir olmuştur (Peçevî 1866, cilt I, 328; Hasan Bey-zade 2004, cilt II, 135).

Bu seferden dönüşte Selanik ve Yenişehir civarında Şehzade Mustafa olduğunu iddia eden bir sipahinin ortaya çıktığı haber alınmış ve üçüncü vezir Mehmed Paşa üç bin yeniçeri ve dört bölük ağası ile derhal Rumili'ye sevk edilmiştir. Mehmed Paşa Edirne'ye geldiği sırada asilerin başı Niğbolu sancakbeyi Zulkadirli Mehmed Han tarafından ele geçirilerek önce Rumili bölgesinin muhafazası için Edirne'de bulunan Şehzade Bayezid'e ve onun vasıtasıyla İstanbul'a gönderilmiş ve divanda sorgulandıktan sonra idam edilmiştir (Peçevî 1866, cilt I, 342; Âlî 2009, cilt I, vr.336b; Celalzade 2011, 345; Turan 2011, 58; Ahmed Refik 2017, 12).

Sokollu Mehmed Paşa'nın geleceğinin şekillenmesinde son derece önem arz eden olaylar 1558 yılında yaşanmıştır. Şehzade Selim'in Manisa sancağını, Şehzade Bayezid'in Kütahya sancağını 
yönettiği sırada Sultan Süleyman her iki şehzadeye de emir göndererek Selim'i Konya'ya, Bayezid'i ise Amasya'ya nakletmiştir. Selim, Sultan'ın bu kararına boyun eğerken Bayezid İstanbul'dan uzakta bir sancağa atanmasını kabul etmek istememiş ve Sultan'a rica mektupları göndermiştir. Ancak ricalarının karşılık bulmaması üzerine, Bayezid Amasya'ya gitmek üzere yola çıkmış, fakat Kütahya'dan yola çıkan kafilesi oldukça yavaş hareket etmiştir. Bunun üzerine Sultan Süleyman, kafilenin hızlanması ve bir an evvel Amasya'ya ulaşmasını sağlamak için Bayezid'e dördüncü vezir Pertev Paşa'yı göndermiştir. Aynı zamanda Bursa yakınlarında bulunan Şehzade Selim'e nasihat için de Mehmed Paşa görevlendirilmiştir (Âlî 2009, cilt I, vr.341a; Turan 2011, 86). Bunun üzerine Bayezid Amasya'ya gittiyse de Selim'le aralarındaki anlaşmazlık karşılıklı mektuplar vasıtasıyla gün geçtikçe artmıştır. Aynı zamanda Bayezid'in lalası Mustafa Paşa'nın kendisine menfaat sağlamak amacıyla Şehzade Selim'in lehine çalışması da Bayezid'in Sultan Süleyman'ın gözünden düşmesine neden olmuştur. Bayezid'in emrine çok sayıda adam topladığını öğrenen Sultan Süleyman, Anadolu, Karaman, Zulkadriye ve Adana beylerine emir göndererek Konya' da toplanmalarını ve Bayezid'in bir hareketi olması durumunda Selim'e yardım etmelerini istemiştir. Ayrıca Sultan, Selim'e yardım etmesi amacıyla üçüncü vezir Sokollu Mehmed Paşa'yı da üç bin yeniçeriye ilaveten silahdar ve topçu bölükleriyle birlikte Konya'ya göndermiştir. Konya Ovası'nda gerçekleşen savaşta mağlup olan Bayezid, çocuklarıyla birlikte önce Amasya'ya ardından İran'a firar etmiştir. Bayezid'i takip eden Şehzade Selim ve Sokollu Mehmed Paşa birlikte Haleb'de kışlamışlar, ardından Selim Konya'ya, Mehmed Paşa da maiyetindeki askerlerle birlikte İstanbul'a dönmüştür. Gönderilen elçiler vasıtasıyla Bayezid'in teslimi için İran şahıyla anlaşılmış ve Şehzade Bayezid dört oğluyla birlikte boğularak öldürülmüştür (Peçevî 1866, cilt I, 385 vd).

Sadrazam Rüstem Paşa'nın 1561 yılında vefat etmesi üzerine sadrazamlığa Semiz Ali Paşa getirilmiş, ikinci vezirliğe de Sokollu Mehmed Paşa geçmiştir (Afyoncu 2009a, cilt XXXVII, 355). Sokollu Mehmed Paşa, 1562 yılında Şehzade Selim'in kızı İsmihan Sultan ile evlenerek hanedan damadı olmuştur (Âlî ve ondan naklen Peçevî, Mehmed Paşa'nın İsmihan Sultan'la evlendiği sırada üçüncü vezir olduğunu kaydetmiştir. Peçevî 1866, cilt I, 25; Âlî 2009, cilt I, vr.361a; Lamartine, İsmihan Sultan'ın Mehmed Paşa'yla evlendiğinde on altı yaşında olduğunu belirtmiştir. Lamartine 2008, 460). 1565 yılı Haziran ayında Sofya'ya doğru yola çıkan sadrazam Semiz Ali Paşa'nın Çatalca'da vefat etmesi üzerine padişahın mührü o sırada ikinci vezirlikte bulunan Sokollu Mehmed Paşa'ya verilerek sadrazamlığa getirilmiştir (Selanikî 1999, 8; Sokollu Mehmed Paşa'nın ölümünden sonra İsmihan Sultan, Budin beylerbeyi Ali Paşa ile evlenmiştir. Âlî 2009, cilt I, vr.525a-525b).

Bu sıralarda Macar kralının senelik vergisini göndermemesinin yanı sıra Göle, Tımışvar ve Sigetvar kalelerini tahkim ettirmesi üzerine Sultan Süleyman'ın son seferi için hazırlıklara başlanmıştır (Selanikî 1999, 11). Sultan Süleyman'ın Sigetvar'a yaklaştığı sıralarda Sokoloviç ailesini ilgilendiren olaylar da yaşanmıştır. Budin beylerbeyi olan Yahyapaşazade Arslan Paşa, Avusturya imparatoru ile yazışmalarında imparatorun vergi göndermesi ve barış istemesi durumunda Osmanlı tarafının bunu kabul edeceğini belirtmiştir. Ancak bu vaatlerin gerçekleşmemesi, divanda Arslan Paşa aleyhinde faaliyet yürütülmesine neden olmuştur (Altaylı 2006, 45). Arslan Paşa bir süre sonra padişahın sefere çıktığı haberini alınca padişah emri olmadığı halde İstolni Belgrad (günümüzde Székesfehérvár) yakınlarındaki Palota kalesini kuşatmıştır. Kuşatma sürerken Arslan Paşa'nın casuslarının dört bin kadar düşman askerinin geldiğini bildirmesi üzerine top ve çadırlar bırakılarak askerler geri çekilmiştir. Ancak Avusturya askeri, Tata ve Vesprim kalelerini ele geçirmiş, halkı da esir etmiştir. Bu haberler Osmanlı ordugâhına geldikten sonra Sultan Süleyman'ın Sokollu Mehmed Paşa'dan hesap sorması üzerine sadrazam, Arslan Paşa'ya defalarca mektup gönderdiğini, padişahın serhadde gelmesine rağmen 
kendisinin neden orduya gelmediğini sorduğunu ancak cevap alamadığını belirtmiştir (Selanikî 1999, 25). Kuşatmada başarısız olmasının yanı sıra, aleyhinde yürütülen faaliyetler de Arslan Paşa'nın sonunu hazırlamıştır. Sultan, çavuşbaşının çavuşlar ve kapıcılar ile Budin'e giderek Arslan Paşa'nın başını getirmesini emretmiştir. Bu esnada Arslan Paşa'nın kethüdası, paşanın üç gündür yolda olduğunu ve ertesi gün orduya geleceğini bildirmiş ve padişaha iletilmek üzere arzını vermiştir. Padişah, Arslan Paşa'nın arzını okuduktan sonra sadrazama "asker serhaddeyken arzuhal etmeye gelirmiş, kendi çadırında boğdurasın" şeklinde emrini göndermiştir. Ancak Sadrazam ertesi gün divanın toplanmasını ve Arslan Paşa beylerbeyi olduğu için emrin divanda uygulanmasını önermiştir. Arslan Paşa geldiğinde Sokollu Mehmed Paşa "leşkeri kime ısmarladun, sözün nedür? Saadetlü padişah sana beylerbeyilik buyurdu, hayf senin namına, sen tilki de değilmişsin" şeklinde tahkir ederek çavuşbaşından idam emrini yerine getirmesini istemiştir. Bu sırada Arslan Paşa'nın can havliyle yeninden çıkardığı iki mektubu da sadrazam almıştır. Arslan Paşa'nın katlinden sonra Budin beylerbeyliği ise Sokollu Mehmed Paşa'nın amcazadesi Mustafa Paşa'ya tevcih edilmiştir (Peçevî 1866, cilt I, 416; orduyla birlikte Sigetvar seferinde bulunan müellif Selanikî, Arslan Paşa'nın Sokollu Mehmed Paşa aleyhinde arzlarda bulunmasının da gözden düşmesinde etkili olduğunu belirtmiştir. Selanikî 1999, 26; Hasan Beyzade Tarihi'nde de Arslan Paşa'nın idam edilmesinde Sokollu Mehmed Paşa'nın padişahı etkilemesinin rol oynadığı kaydedilmiştir. Hasan Bey-zade 2004, cilt II, 144; Arslan Paşa'nın iki devlet arasında barışı tesis etme konusunda başarısız olmasında, maiyetindeki Macar asıllı kâtiplerin Avusturya imparatoruna istihbarat sağlaması da etken olmuştur. Altaylı 2006, 40-41).

Ordunun Sigetvar üzerine yürüdüğü sırada Sokollu Mehmed Paşa, nikristen muzdarib olan padişahın acılarını azaltmak için varılacak menzillerin geçitlerini kontrol ettirmiş ve arabaların geçeceği yolları düzelttirmiştir (Selanikî 1999, 18). Sadrazam, Sigetvar kuşatması devam ederken bir ölüm tehlikesi atlatmıştır: Olay şöyle cereyan etmiştir: Kaleye doğru ilerleyen askerlerle birlikte Mehmed Paşa da yürüyüşe geçmiştir. Bu sırada Mehmed Paşa'nın önünde bulunan Çaşnigir Ali Ağa şehid düşmüştür. Kaleden atılan bir darbzen topu ise Mehmed Paşa'nın bulunduğu yere düşmüş, katip Feridun Bey onu kendi üstüne çekip yıkarak ölümden kurtarmıştır. Topun düştüğü yerde bulunan birçok asker ise şehid düşmüştür. Durumu öğrenen Sultan Süleyman, sadrazama bir tezkire göndererek onun metrislere girmesine, yürüyüşlere katılmasına rızası olmadığını, askerlerin ihtiyaçlarının karşılanması için çalışması gerektiğini bildirmiştir. Feridun Bey ise dergah-1 ali müteferrikalığı ile taltif edilmiştir (Selanikî 1999, 30; Feridun Bey, Sigetvar seferinin öncesini, seferi ve II. Selim'in tahta cülusunu detaylarıyla anlattığ 1 bir eser kaleme almıştır. Detaylı bilgi için bkz. Feridun Ahmed Bey 2012).

Sultan Süleyman'ın Sigetvar kuşatmasının son günlerine doğru ölmesi ve Mehmed Paşa'nın padişahın ölümünün ordugâhta duyulmaması için harcadığı çaba dönemi anlatan müellifler tarafından takdirle karşılanmıştır (Hasan Bey-zade 2004, cilt II, 152; Âlî 2009, cilt I, vr.353a). Paşa ilk olarak kethüdası Hasan Çavuş ile Şehzade Selim'e haber göndermiştir. Ayrıca, padişahın ölümünün askerler tarafından duyulmasının orduda itaatsizliğe neden olacağını öngörerek çeşitli tedbirler almıştır. Padişahın ölümünü vezirlerden dahi gizleyen Mehmed Paşa, zaman zaman otağ-1 hümayuna girerek huzura çıkıyor gibi davranmış, sözde padişahın verdiği emirlerin uygulanması için çaba harcamıştır. Mehmed Paşa'nın bu işte elini kolaylaştıran kişiler ise Paşa'ya yakınlığı ile bilinen Nişancı Feridun Bey ve o dönemde silahdar olan, ileride ise Sokollu Mehmed Paşa'nın damadı olacak olan Cafer Ağa olmuştur. Padişahın cesedi araba ile taşınırken Sokollu Mehmed Paşa arabanın yanına sokularak arzlarda bulunmuş, yazısı Sultan Süleyman'ın yazısına benzeyen Cafer Ağa da buna mukabele etmiştir. Şehzade Selim hızla hareket ederek Belgrad'a gelmiş ve bu sırada ordu da Belgrad'a doğru yola çıkmıştır. Ordunun Belgrad'a gelişinin ertesi günü devlet erkânı Sultan Selim'e biat etmiş ve merhum padişahın cenaze namazı kılınmıştır 
(Peçevî 1866, cilt I, 421-423).

\section{Selim ve Sokollu Mehmed Paşa}

II. Selim'in tahta cülus ettiği ilk günlerde yaşananlar hem padişahı hem de Mehmed Paşa'yı oldukça zorlamıştır. Kroniklerin deyimiyle "asker içindeki bazı ehl-i fesad" cülus bahşişinin verilmeyeceği söylentisini yaymıştır. Bu durum yeniçerilerin infialine neden olmuş ve padişah ile divan erkânını ortalarına alarak İstanbul'a girmelerine izin vermemişlerdir. Hatta yeniçeriler aralarında Sokollu Mehmed Paşa'nın da bulunduğu vezirlere saldıracak kadar ileri gitmişlerdir. Sultan Selim yeniçerilere bahşiş dağıtılacağı sözünü verince sorun çözülmüştür (Hasan Bey-zade 2004, cilt II, 196-198).

II. Selim saltanatının tamamı (1566-1574), Sokollu Mehmed Paşa'nın sadrazamlığı ile geçmiştir. Bu durum için Peçevî, Âlî’den naklen "Sultan Selim asrında hod pâdişâh -ı manevî idi. Vüzerâdan birine müyesser olmayan istiklâl ile imtiyâz bulmuşidi" ifadelerini kullanmıştır (Peçevî 1866, cilt I, 25). Âlî ise Sokollu Mehmed Paşa'nın, padişahın damadı olması münasebetiyle "iltifât-ı bî-nihâyesine mazhar" olduğunu ve sadrazamın "padişah-ı sûrî" olduğunu kaydetmiştir (Âlî 2009, cilt I, vr.451a, vr.482b). II. Selim tahta çıkınca sadaret makamında kalan Sokollu sayesinde padişah, Peçevî'nin deyimiyle "lezâyiz-i dünyevîlerine rağbet ve iştigâl göstererek" devlet işlerini sadrazamına bırakmıştır. Böylece Sokollu'nun sadaretinde hiç kimse işlerine karışamamış ve kendisi de adalet duygusuyla hareket etmiştir. Düşmanları, Mehmed Paşa'yı kendi akrabası ve adamlarını önemli mevkilere getirmek dışında bir şeyle suçlayamamıştır. Bununla birlikte Peçevî'ye göre Paşa'nın ileri çıkardığı adamlar zaten o görevlere en layık olan kişilerdir (Peçevî 1866, cilt I, 440).

II. Selim döneminde Sokollu Mehmed Paşa'nın gerçekleştirmeyi düşündüğü önemli projeler olmuştur. İran üzerine yapılacak seferlerde donanmanın da kullanılmasını isteyen Mehmed Paşa, 1569 yılında aralarında az bir mesafe olan ve Karadeniz'e dökülen Ten ve Hazar Denizi'ne akan İtil nehirlerinin birleştirilmesi için girişimlerde bulunmuştur. Bu amaçla ikinci defterdar Çerkes Kasım Bey Kefe sancakbeyliğine atanmış ve proje için ön çalışmalar başlamıştır. Kasım Bey'in yaptırdığı ölçümler ile iki nehir arasındaki mesafenin altı mil olduğu anlaşılmış ve bu proje gerçekleşirse İran üzerine yapılan seferlerde lojistik sıkıntısı çekilmeyeceği ve bölgede Osmanlı hâkimiyetinin pekişeceği kanaatine varılmıştır. Bunun üzerine Sokollu Mehmed Paşa gerekli araç-gereçleri ve askerleri donanmayla Kefe'ye göndermiş, Kırım hanına da bütün askeriyle Kasım Bey'e yardım etmesini emretmiştir. Osmanlı askeri Deşt-i Kıpçak'ı aşıp Ejderhan önlerine gelip kanal çalışmalarına başlamıştır. Çalışmaların üçte birlik kısmı tamamlandığında asker arasında kışın erken geleceği ve bu işin tamamlanamayacağı söylentisi çıkmıştır. Peçevî’ye göre projenin gerçekleşmesi durumunda Tatarların gözden düşeceğini ve Kırım'ın kontrolünden çıkacağını düşünen Kırım hanı tarafından çıkarılan bu söylenti nedeniyle çalışmalar yarım kalmıştır. Oldukça masraflı olan bu girişimin başarısız olması Sultan Selim'i kızdırmış ve vezirlerin önünde Sokollu Mehmed Paşa'yı azarlayarak harcanan paranın kendisinden tazmin edilmesini istemiştir (Peçevî 1866, cilt I, 468-470; Âlî 2009, cilt I, vr.430a).

Sokollu Mehmed Paşa'yı en çok zorlayan olaylar 1571 yılında meydana gelmiştir. Bu dönemde Venedik'in elinde bulunan Kıbrıs adası, Osmanlı kontrolündeki İstanbul-İskenderiye deniz yolu güvenliğini tehlikeye düşürmekteydi. Osmanlıların Doğu Akdeniz'deki hakimiyetini güvence altına almak için elzem olan adanın fethi konusunda kronik yazarları birbirinden farklı nedenler göstermiştir. Bu dönemde yaşamış olan müelliflerden Selanikî, II. Selim'in şehzadeyken bazı mallar satın almaları için Kıbrıs'a gönderdiği adamlarının burada alıkonulduklarını, bu durumun da şehzadede Kıbrıs'ın fethi için özel bir hassasiyet oluşturduğunu belirtmiştir. Âlî, Mısır'a giden 
gemilerin Kıbrıs civarında yağmalandığını, Venediklilerden bu durumla ilgili bilgi istendiğinde ise bunun Malta ve Messina civarından gelen korsanlar tarafından yapıldığını söylediklerini kaydetmiştir. Bunun yanı sıra müellif, Kıbrıs'ın Hz. Ömer zamanında Müslümanlarca fethedildiğini ve bu dönemde yapılan caminin domuz kesimhanesine dönüştürüldüğünü, divan katipliğini yaptığı Lala Mustafa Paşa'nın Şam valiliği sırasında Kıbrıs anıldığı zaman büyük bir üzüntü duyduğunu belirterek, Kıbrıs seferinin nedenlerini sıralamıştır. Peçevî de eserinde Kıbrıs seferiyle ilgili kısmı Âlî'den naklen tekrarlamıştır (Peçevî 1866, cilt I, 486-487; Selanikî 1999, 77; Âlî 2009, cilt I, vr.444a-444b;). Kronik yazarları Sokollu Mehmed Paşa'nın Kıbrıs seferine dair tutumu hususunda sessiz kalmayı tercih etmiştir. Hammer ve Jorga ise Kıbrıs seferinin Sokollu Mehmed Paşa'nın muhalefetine rağmen ikbal kaygısı güden sabık kapudan Piyale Paşa ve Lala Mustafa Paşa'nın yanı sıra Kıbrıs kralı olma emelleri taşıyan Jozef Nasi isimli bir Musevi'nin Sultan Selim'i kışkırtması ile gerçekleştirildiğini aktarmıştır (Hammer 1332, cilt VI, 241-242; Jorga 2005, cilt III, 126-128; bütün bu kayıtlar değerlendirildiğinde sadrazam Sokollu Mehmed Paşa'nın karşı çıkmasına karşın vezirlerin desteğiyle sefere karar verildiği gibi bir sonuç çıkmaktadır ki, başarıyla sonuçlanan seferin ardından muhalif olmasına rağmen Sokollu Mehmed Paşa'nın mevkiini koruması, tecrübeli sadrazamın sefer karşıtı görünerek Batılı devletlerin elçilerini teskin ettiğini ve savaş hazırlıklarının gizlice sürdürüldügünü düşündürmektedir. Emecen 2013, 181-182).

Kıbrıs'ın kaybını engellemek isteyen Venedik'in Papa'dan yardım istemesi üzerine Papalık, İspanya ve Malta şövalyeleri donanma göndermiştir. 1570 yılının Mayıs ayında Girit adasında birleşmek üzere anlaşan müttefiklerden Venedik buraya gelmişse de diğerleri geç kalmıştır. Müttefik donanması birleşip Girit’ten ayrıldığı sırada Lefkoşa'nın Osmanlıların eline geçtiği haber alınmış ve sefer mevsiminin geçmesi nedeniyle donanma tekrar Girit'e dönmüştür. Ertesi yıl İtalya yarımadasındaki küçük devletlerin de desteklediği büyük bir donanma Messina limanından hareket etmiştir. Kuşatma sırasında Lala Mustafa Paşa'nın talebi üzerine Osmanlı donanmasının bir kısmı kapudan-1 derya Müezzinzade Ali Paşa kumandasında Kıbrıs'a gönderilirken, büyük kısmı ise Pertev Paşa emrinde Akdeniz'e açılmıştır. Adanın fethinin ardından kapudan paşa da Rodos civarına gelmiş ve burada birleşen Osmanlı donanması önce Girit, ardından Mora kıyılarına giderek müttefik donanmasını aramıştır. Mora'nın kuzeyindeki İnebahtı körfezinde yapılan büyük muharebede Osmanlı donanması ağır bir mağlubiyete uğramış, buna rağmen müttefik donanması herhangi bir yeri ele geçiremeden dağılmıştır (Hammer 1332, c.VI, 265-271).

İnebahtı'da uğradığı ağır mağlubiyetle neredeyse yok olma durumuna gelen Osmanlı donanması, sadrazam Sokollu Mehmed Paşa'nın ve kapudan-1 derya Kılıç Ali Paşa'nın yoğun çalışmalarıyla bir yılda eski gücüne kavuşturulmuştur. Bu hususta Sokollu Mehmed Paşa'nın Kılıç Ali Paşa'ya söylediği söz, devletin gücünü ve kararlıllı̆ını göstermesi bakımından önemlidir:

lâzım gelürse, her kadırganun resenlerini ibrişimden ve tente vü yelkenlerini atlas u dîbâdan iderün. (Peçevî 1866, cilt I, 498-499; Hasan Beyzade 2004, cilt II, 209-210; Âlî, bu dönemde iki yüz parça kadırga ve mavnanın denize indirildiğini kaydetmiştir. Âlî 2009, cilt I, vr.449a).

Ancak böyle bir ifade Selanikî'nin eserinde yer almamaktadır. Selanikî, İnebahtı mağlubiyetini anlattığı bahsin ardından Kılıç Ali Paşa'nın İstanbul'a dönüşünden sonra tersanelerde yoğun çalışmalar sonucunda yeni bir donanma vücuda getirildiğini kaydetmiş, bu hususta Sokollu Mehmed Paşa'nın katkısına dair bir bilgi vermemiştir (Selanikî 1999, 84-85). 


\section{Murad ve Sokollu Mehmed Paşa}

Sultan Selim döneminde iktidarı sorunsuz devam eden Sokollu Mehmed Paşa için işler, tahta III. Murad'ın geçmesiyle değişmiştir. Âlî, Sultan Murad'ın yakınlarının Mehmed Paşa'ya olan düşmanlıklarını su yüzüne çıkardıklarını ve ellerine fırsat geçtikçe sadrazamın azli için, belki de katli için padişahı onun aleyhinde kışkırttıklarını kaydetmiştir. Bu hususta padişaha sadrazamın her söylediğine inanmamasını salık veren Mehmed Paşa karşıtı hizip, padişahın şikâyet arzlarını bizzat kontrol etmesini sağlamışlardır. Ancak bir süre sonra herkes düşmanını şikâyet etmeye başlamış ve durum içinden çıkılmaz bir hal almıştır (Âlî 2009, cilt I, vr.478b). Peçevî’ye göre ise III. Murad henüz tahta çıkmadan evvel başta Üveys Paşa olmak üzere yakınları tarafından Sokollu Mehmed Paşa aleyhinde doldurulmuştur. Ayrıca sadrazam ile arası açık olan Rumili kadıaskeri Kadızade'nin de padişaha sürekli olarak Mehmed Paşa'nın rüşvet aldığı kişileri ve yakınlarını kayırdığı şeklindeki sözleri, III. Murad'ın Mehmed Paşa aleyhinde düşünceler edinmesine neden olmuştur (Peçevî 1866, cilt II, 6).

III. Murad'ın tahta cülus için İstanbul'a geldiği gün yaşananlar, yeni padişahın içten içe Sokollu'ya kin beslemesine neden olmuştur. Peçevî’nin Tiryaki Hasan Paşa'dan işitip naklettiğine göre bu konudaki olaylar şu şekilde gelişmiştir: Tahta çıkacak padişahı almak için Mudanya'ya gönderilen kadırga padişahın olduğu yerde değil, başka bir mahalde beklemiştir. Padişahın bulunduğu yerde ise Nişancı Feridun Bey'in buz kayığı bulunmaktadır. Padişah ve maiyetinde bulunan silahdarı İbrahim Paşa, çukadarı Mehmed Paşa ve rikabdarı Hasan Paşa birlikte kayığa binerek yola çıkmışlardır. Yolda firtınaya yakalanan padişah ve maiyetini deniz tutmuştur. Padişah, Tiryaki Hasan Paşa'nın dizi üstüne yatarak yolculuğu tamamlamıştır. Ahırkapı'ya gelip kapının açılmasını isteyen padişah ve adamları Bahçekapı'ya yönlendirilmiştir. Bir süre sonra sadrazam Mehmed Paşa, kayığıyla gelerek padişahı karaya çıkarmıştır. Kardeşlerinden birisinin tahta cülus ettiğini düşünen III. Murad eğilerek yaşlı sadrazamın elini öpmek istemiş fakat Mehmed Paşa hızlı davranarak yeni padişahın elini öpmüştür. Bahçekapı' dan giren padişaha getirilen şerbeti önce Mehmed Paşa içmiş ve ardından padişaha sunulmuştur. Sokollu'nun bu hareketi padişahın zihninde yer etmiş ve etrafındaki paşaların kışkırtmaları padişahın Sokollu'ya kin tutmasına neden olmuştur (Peçevî 1866, cilt I, 26-27).

Bütün bunlara rağmen III. Murad saltanatında da Sokollu'nun gücü devam etmiştir. Padişahın tahta çıktığ 1 ilk günlerde, adet olduğu üzere Eyüp Sultan türbesi ziyaret edilirken padişaha Sokollu Mehmed Paşa "atabeylik" etmiştir (Selanikî 1999, 106). Bununla birlikte III. Murad döneminde Sokollu'nun maruz kaldığı davranışları Hasan Beyzade tafsilatıyla anlatmıştır. Müellif, III. Murad'ın Mehmed Paşa gibi iş bilir bir devlet adamının işleri yürütmesine imkân vermeyip, devlet işlerini bizzat eline aldığını belirtmiştir. Bu durumun Sokollu Mehmed Paşa'yı korkuya sevk ettiğini belirten müellif, sadrazamın ne şekilde sultanın gözüne gireceğini bilemediğini, ayrıca Musahib Şemsi Paşa gibi rakiplerinin de sadrazam aleyhinde padişahı kışkırttıklarını belirtmiştir (Hasan Bey-zade 2004, cilt II, 254).

III. Murad'ın kini öncelikle Sokollu'nun yakın çevresini hedef almıştır. Bundan ötürü Nişancı Feridun Bey azledilmiş ve Feridun Bey'in kethüdası katledilmiştir (Hasan Bey-zade 2004, cilt II, 255; III. Murad'ın Feridun Bey'e karşı olan tavrı daha önce yaşanan bir olayla da ortaya çıkmıştır. Osman Gazi'den III. Murad'a dek padişahlar tarafindan diğer devletlere gönderilen ve onlardan gelen namelerin derlendiği bir eser vücuda getiren Feridun Bey, eserini sadrazam Sokollu Mehmed Paşa vasıtasıyla padişaha arz etmiştir. Tarihçi Selanikî'nin "bî-bedel ve bî-nazîr olduğunda kimsenin şübhesi yokdur" diye nitelediği bu eser, III. Murad'dan hak ettiği iltifatı görmemiştir. Selanikî 1999, 110). Ardından paşanın kethüdası Hüsrev'i (Sokollu Mehmed Paşa'nın kapısından çıkarıldıktan sonra Çıldır beylerbeyliğine tayin edildiği anlaşılan Hüsrev 
Kethüda, 1585 yılında şehit düşmüştür. Peçevî 1866, cilt II, 101; Âlî 2009, cilt I, vr.533b) ve kapıcıbaşısı Sinan Ağa'yı kapısından çıkarması emredilmiştir. Sokollu'nun amcazadesi olan Budin beylerbeyi Mustafa Paşa, Sokollu'dan gizli bir şekilde gönderilen mirahur-1 kebir Ferhad Ağa tarafından öldürülmüştür. Paşanın kapı halkından on dokuz ağanın zeametleri "havass-1 hümayuna layıkdır" denilerek defterdar Üveys Paşa'ya verilip paşanın adamlarına verimsiz timarlar verilmiştir. Sokollu, yapılan bu muamelelere karşın padişaha sadakatinden asla geri adım atmamış ve hizmetine devam etmiştir (Peçevî 1866, cilt II, 8; Hasan Bey-zade 2004, cilt II, 257; Âlî 2009, cilt I, vr.482b-483a). Hasan Beyzade, o dönemde Kadızade'nin devlet işlerinde Sokollu Mehmed Paşa'ya karıştığını ve sadrazamın Kadızade Şemseddin Ahmed'in müdahalesinden ölümüne dek kurtulamadığını kaydetmiştir (Hasan Bey-zade 2004, cilt II, 259; Kadızade, İstanbul'da müderrislik yaparken Sokollu Mehmed Paşa ile aralarındaki anlaşmazlık yüzünden 1573 yılında Edirne Darülhadisi'ne gönderilmiştir. İki yıl sonra Süleymaniye Darülhadisi'ne tayin edilen Kadızade, 1577 yılında şeyhülislamlığa getirilmiştir. İpşirli 2001, 96).

Artık iyice yaşlanan Sokollu Mehmed Paşa'nın otoritesi gün geçtikçe azalmıştır. 1577 yılında Van beylerbeyi Hüsrev Paşa'nın, İran şahı İsmail'in öldüğü ve yerine kör olan kardeşinin geçtiği, bu fırsatın kaçırılmaması gerektiği yolundaki arzı üzerine Sultan Murad bir serdar tayin edilerek sefere çıkılmasını emretmiştir. Sadrazam Mehmed Paşa ise sefere çıkılırsa kul taifesinin azacağını, giderlerin artacağını, dolayısıyla artacak olan vergilerden ve askerlerin uygunsuz hareketlerinden ötürü halkın perişan olacağını, İran fethedilse bile halkının Osmanlı hâkimiyetini kabul etmeyeceğini belirterek sefere engel olmak istemiştir. Sultan Süleyman'ın İran ile barış1 tesis edene dek çok sıkıntılar çektiğini belirten sadrazam, savaş taraftarlarını ise "İran seferinin ne demek olduğunu bilmeyenler ve at ve davardan ayrllp öküze binmeyenler" olarak nitelendirmiştir. Ancak sadrazamın bütün çabaları boşa gitmiş ve İran üzerine sefer açılmış ve serdarlığa üçüncü vezir Lala Kara Mustafa Paşa getirilmiştir (Peçevî 1866, cilt II, 36-37; Hasan Bey-zade 2004, cilt II, 261).

\section{Sokollu Mehmed Paşa'nın Şehadeti}

Uzun yıllar sadrazamlık makamında bulunan ve kroniklerin deyimiyle "devleti istediği gibi idare eden" Sokollu Mehmed Paşa'nın ölümü de gönlünden geçtiği gibi olmuştur. Peçevî İbrahim'in Mehmed Paşa'nın hazinedarı Hasan Ağa'dan naklettiğine göre Mehmed Paşa her gece namaz kıldıktan sonra Hasan Ağa'ya Osmanlı tarihi okuturmuş. O gece Hasan Ağa ne okuyalım diye sorunca paşa "Sultan Murad'ın Kosova'da şehadetini oku" diye karş1lık vermiştir. Hasan Ağa ilgili bölümü okurken paşa, gözlerinden yaş süzülerek "bana da böyle bir şehadet nasib eyle ya Rab" diye dua etmiş, Peçevî'nin ifadesiyle "tir-i duası hedef-i icabete isabet" etmiştir. Ertesi gün ikindi divanında âdeti üzere paşadan harçlık almaya gelen divaneyi gören paşa, ona vermek üzere cebinden akçe çıkarmıştır. Akçeyi divaneye vermek üzereyken adam yeninden çıkardığı bir hançer ile yaşlı paşayı göğsünden yaralamış ve darp etmiştir. Paşanın adamları derhal adamı yakalamış ve hapsetmişlerdir. Paşanın hizmetkârı Üstad Ali isimli cerrah çağrılmış fakat yapılan müdahaleye rağmen paşa kurtarılamamış ve vefat etmiştir (Hasan Beyzade ve Peçevî, Sokollu'nun ölüm tarihini 8 Şaban 987 (30 Eylül 1579) olarak göstermektedir. Peçevî 1866, cilt I, 25; cilt II, 62; Hasan Bey-zade 2004, cilt II, 276; Peçevî, sadrazamın ölüm haberinin doğuda seferde bulunan serdara ve orduya 6 Ramazan (27 Ekim) günü vasıl olduğunu belirtir. Selanikî ve Âlî ise ölüm tarihini 20 Şaban 987 (12 Ekim 1579) olarak göstermektedir. Selanikî 1999, 125; Âlî 2009, cilt I, vr.506a).

Paşa'nın ölümü üzerine "Hükm-i Hakk ile şehid oldu Mehemmed Paşa" şeklinde tarih düşürülmüştür. Yine Misalî’nin yazdığı dörtlüğün son mısrası da bu tarihi belirtmektedir: 
Birisi eksilecek paşanun

Acıyub bir yire geldi şuara

Ey Misali didiler tarihin

Hayf kim gitdi Mehemmed Paşa. (=sene 987).

Sokollu Mehmed Paşa öldükten sonra üç bine yakın kulu siyah giyip yas tutmuştur. Cenazesi ertesi gün Kadızade'nin imamlığında kaldırılmış ve Eyyub Ensari'nin türbesinde defnedilmiştir. Paşanın katili parça parça edilerek İstanbul'un dört kapısına bırakılmıştır. Cenazeden sonra mühri hümayun yas nedeniyle kimseye verilmemiş ve üçüncü günün sonunda kapıcılar kethüdası ile Ahmed Paşa'ya gönderilmiştir (Hasan Bey-zade 2004, cilt II, 276-80).

Akrabası olması dolayısıyla Peçevî İbrahim Efendi'nin eserinde Sokollu Mehmed Paşa'ya toz kondurmadığ 1 dikkati çekmektedir. Müellif, Rüstem Paşa'nın aldığı rüşvetlerle pek çok kez töhmet altında kaldığı bir dönemde Mehmed Paşa'nın mal varlı̆̆ını kethüda ve hazinedarından naklen şu şekilde açıklamaktadır:

"(merhûm vezir-i azam irtişa almazdı) dirsiz ve (hasları yüz elli-yüz altmış yük akçeden ziyade olmazdı buyurursuz) ya bu iki saraya bin yük akçe, Burgaz imaretine üç yüz yük, ve Hafsa imaretine yüz elli yük, sairi dahi Ístanbul'da, Kasımpaşa'da, Haleb'de, Şam'da, Mekke'de ve Medine-i Münevvere'de bu imarat ve bu evkaf mesarifi ne yerden hasil oldu dedim, buyurdular ki (şimdi sahib-i devlet olduğu irtişadan bizim merhuma gelen hedaya iki üç mertebe ziyade idi. Ebniyeden gayri mesarifi ekser hediye tarikiyle gelürdü. Bu imaretlerinde hıdmet eder bin nefer forsa kulu var idi. Evvela Yeni Saray ki cami-i cedid-i Sultan Ahmed Han kurbunda vakıdır. Anın binasıçün Sultan Selim-i Merhum duhter-i pakizeahterlerine ki anların ıkdamıyla binasına mübaşeret olunmuşdur, binasina Sultan Selim merhum yüz bin altun imdad etdi ve lakin merhum almayub sultana hediye etti yani bunun gibi tayyarata nihayet yoğidi. Bu cümleden kat-ı nazar on altı yll vezir-i azam oldu. Yüz altmış yük akçe haslar mahsulü ol hesab üzere cümle dört yüz bin guruş ederdi. On altı yılda dört yüz bin guruşdan heman bir kalem ne kadar mal olur ve aşă̆a vezareti dahi dokuz yıl idi. Senede yüz bin guruş olur, yalnız bunu kaleme alın, andan sonra bu kadar binaya giden mal kandan hasıl oldu sual buyurun. Filvaki kendüler ile hesab etdik. Yetmiş seksen kere yüz bin guruşa durmuşdu. Ya bu makama gelince olan tahsilleri sana caba" deyu latife etdiler".

Bu ifadelere daha sonra da devam eden İbrahim Efendi, Sokollu Mehmed Paşa'nın maiyetinden Kaytas Kethüda ve hazinedarı Hadım Hasan Ağa'ya, Mehmed Paşa'nın rüşvet almadığını söylemelerine rağmen bunca servetin ne şekilde hasıl olduğunu sormuştur. Paşa'nın adamları cevap olarak Paşa'ya gelen hediyelerin, o devirde sadrazamların aldıkları rüşvetten daha fazla olduğunu, paşanın yaptırdığı imaretleri bu şekilde finanse ettiğini belirtmişlerdir (Peçevî 1866, cilt I, 10-12).

Rumen tarihçi Jorga ise bu hususta Alman kaynaklarından naklen Paşa'nın Venediklilerden ve Almanlardan, ayrıca Eflak ve Boğdan'dan aldığı paraların miktarının günlük 5 bin altın, yılda ise 1 milyon altını bulduğunu belirtmektedir (Jorga 2005, cilt III, 153-154). Âlî, III. Murad'ın musahibi Şemsi Ahmed Paşa'nın, padişahı Mehmed Paşa'nın mansıpları rüşvetle verdiğine inandırdığını ve padişahın da rüşvet almaya başladığını kaydetmiştir (Âlî 2009, cilt I, vr.480b). 
Peçevî, Sokollu Mehmed Paşa'nın rüşvet alma suçlamasıyla karşılaşmamasına rağmen, kendi adamlarını önemli mevkilere getirip, hak edenlerin yükselmesine mâni olması nedeniyle suçlandığını aktarmaktadır (Peçevî 1866, cilt I, 10). Âlî ise bu hususta Sokollu Mehmed Paşa'nın "padişah-1 maneviliği zamanında serkeşlik ederek" Ahmed Paşa ikinci vezir olduğu halde sadrazamlık için üçüncü vezir Piyale Paşa'yı onun önüne geçirip mağdur ettiğini kaydetmiştir (Âlî 2009, cilt I, vr.451a). Ayrıca II. Selim zamanında Mehmed Paşa'nın kanuna aykırı olarak bazı vergiler koyarak rüşvet yolunu seçtiğini belirtmiştir (Âlî 2009, cilt I, vr.48a). Bunun yanı sıra Sigetvar seferini anlattığ Heft Meclis isimli bir eser kaleme alan ve bunu Sokollu Mehmed Paşa'ya ithaf eden Âlî, istediği mansıbı alamamış ve bir süre sonra Sokoloviç ailesinden olan Bosna valisi Ferhad Paşa'nın divan katipliğine atanmıştır. Nushatü's-selatin isimli eserinde müellif, II. Selim'in damadı Mehmed Paşa'ya geniş yetkiler verdiğini, sadrazamın da bu yetkileri yalnızca akrabaları ve adamları için kullandığını belirtmiştir (Âlî 2015, 439).

Eserini tahminen 1580 yılı civarlarında III. Murad'a sunan Hırzü'l-Mülûk müellifi ise Sokollu Mehmed Paşa'ya ağır eleştirilerde bulunmuştur. Nasihatname türündeki eserde vezir-i azamların sahip olması gereken özelliklerinin anlatıldığı bahiste, padişahların fethettiği yerlerde vakıflar kurmasının normal olduğu, ancak vezirlere çok sayıda köyün mülk olarak verilmesinin ise insafa sığmayacağı savunulmuştur. Müellif, kulların vezir olmasının zaten onlara yeteceğini, ayrıca onlara köylerin temlik edilmesine gerek olmadığını belirtirken görüşlerini Sokollu Mehmed Paşa ile örneklendirmiştir. Sokollu Mehmed Paşa'ya hem Sultan Süleyman'in hem de Sultan Selim'in pek çok gelir kaynağını temlik ettiğini vurgulayan yazar, bu konuda vezirlerin yazıcılarla anlaşarak yüksek gelirli yerlerin defterde düşük gösterilmesini sağladıklarını belirtmiş̧tir. $\mathrm{Bu}$ sayede vezirlerin, düşük gelirli görünen bu yerleri padişahtan temlik olarak almakta bir sorun yaşamadıklarını, böylece yüksek gelir elde ederek bunları vakıf yoluyla evlatlarına bıraktıklarını kaydetmiştir (Yücel 1988, 177).

Âlî, Mehmed Paşa'nın on dört yıl gibi uzun bir sürede konumu sayesinde elde ettiği gelirler ile Galata'da bir cami, Bergos'ta bir cami, medrese ve imaret, Payas kalasını tamir ile içinde imaret, cami ve kütüphane yaptırdığını kaydetmiş ve maktul sadrazamın diğer hayır işlerinin sayısız olduğunu belirtmiştir (Âlî 2009, cilt I, vr.360b).

\section{Lala (Kara) Mustafa Paşa}

Sokoloviç ailesinden Hüsrev Paşa'nın kardeşi olan Mustafa Paşa, aynı zamanda Mısır sultanı Gavrizade'nin de damadıdır (Âlî 2009, cilt I, vr.451b). Doğum tarihi bilinmemekle birlikte, 1580 yılında öldüğünde yetmiş yaşını geçmiş olduğu göz önüne alınırsa, 16. yüzyılın ilk yıllarında doğduğu kabul edilebilir. Kendisinden daha önce devşirilmiş olan ağabeyi Divane Hüsrev Paşa aracılığ 1 ile devşirildiği ve iç oğlanı olarak hizmete alındığ 1 tahmin edilmektedir (Turan 1958, 552). Hakkındaki kayıtlara göre Sultan Süleyman'a altı yıl boyunca berberbaşlık yapmıştır. Haremden sipahi oğlanları bölüğüne çıkmış, sırasıyla çaşnigir ve mirahur-1 sani olmuştur. Rüstem Paşa'nın sadrazamlığ 1 sırasında tekrar çaşnigirliğe getirilmiş, bir süre sonra saraydan uzaklaştırılmak için Safed sancakbeyliğine tayin edilmiştir. Mustafa Paşa'nın kariyerini şekillendirecek olay 1557 yılında meydana gelmiş ve bu dönemde Şehzade Selim'e lala olmuştur (Kütükoğlu 1979, 732).

1558 yılında Şehzade Selim ve Şehzade Bayezid arasındaki iktidar mücadelesinde, bir dönem Bayezid'in de maiyetinde bulunan Selim'in lalası Mustafa Paşa, Bayezid taraftarı gibi davranarak şehzadeyi Selim aleyhinde kışkırtmış ve nihayetinde Selim'in Bayezid'i bertaraf etmesini sağlamıştır (Detaylı bilgi için bkz. Turan 2011, 67-78). Rüstem Paşa, bu durum üzerine kendisine rakip olacağını düşündüğü Mustafa Paşa'yı Şehzade Selim'in lalalığından alıp 1560 yılında 
Pojega sancakbeyliğine göndermiştir. Ancak Şehzade Selim'in tavassutuyla bir ay sonra Timışvar'a nakledilmiştir. Mustafa Paşa buna rağmen görevine gitmemiş ve Şehzade Selim'in yanında kalmıştır. Birkaç gün sonra görev yeri Van beylerbeyliği olarak değiştirilmiş, 1562'de Erzurum, ertesi yıl ise Haleb ve Şam beylerbeyi olmuştur (Kütükoğlu 1979, 733).

Uzun süre Şam beylerbeyi olarak görevde kalan Lala Mustafa Paşa, Sokollu Mehmed Paşa'nın çabalarıyla hem İstanbul'dan uzak tutulması hem de Yemen'de öldürülen Murad Paşa'nın intikamını alması için Yemen'e serdar tayin edilmiştir. Âlî, bu durumu "Sadrazamın bir taşla iki kuş vurması olarak" nitelemiştir. Mustafa Paşa'nın Yemen seferinde başarılı olmasının şanını yükselteceğinin ve belki de sadrazamlığa geleceğinin farkında olan Sokollu Mehmed Paşa, onun seferde başarısız olması ve padişahın gözünden düşmesi için de bazı tedbirler almıştır. Bu amaçla Mustafa Paşa'nın istediği asker ve mühimmatın temin edilmemesi, Yemen seferinde yardımcı olacak olan Mısır beylerbeyliğine -şehzadeler savaşından sonra firar eden Bayezid'e yardım ettiği için katledilen Ayas Paşa'nın kardeşi- Haleb beylerbeyi Sinan Paşa getirilmiştir. Bu gelişmelerin ardından Mustafa Paşa, Şam beylerbeyliği hasları da kendisine tevcih edilerek 1568 yılında vezaretle Yemen'e serdar olmuştur (Âlî 2009, cilt I, vr.431b).

Mustafa Paşa'nın bu seferde başarısız olması için atılan adımlar bu dönemde de devam etmiştir. Serdara gönderilen emirde Şam'daki yeniçerilerin yarısını hizmetine alması ve o bölgede bulunan "ehl-i fesad" 1 Yemen yeniçerisi yazarak Mısır'a yanında götürmesi, gerekirse Yemen beylerbeyi Osman Paşa'dan da asker ve mühimmat desteği alması gibi hususlar kaydedilmiştir. Kanuna göre bir hizmete tayin edilen vezirlerin maiyetine yeniçeri ve bölük halkından otuz-kırk çavuş gönderilmesi gerektiği halde Mustafa Paşa'ya bu imkân verilmemiştir. Bu nedenlerden dolayı Mustafa Paşa sefere gidemeyeceğini beyan ederek bir süre Şam'da oyalanmış, ancak üst üste gelen emirler sonrası buradan hareket ederek Mısır'a gitmiştir. Burada Mısır beylerbeyi Sinan Paşa, Yemen beylerbeyi Özdemiroğlu Osman Paşa, Mısır kadısı ve defterdarının bulunduğu mecliste Mustafa Paşa'ya gelen emirler okunmuştur. Mustafa Paşa'ya gelen emirde serdarın asker ve mühimmata dair bütün ihtiyaçlarının karşılanması belirtildiği halde, Sinan Paşa'ya gönderilen emirde serdarın istediği şeylerden yalnızca "kifayet mikdarı"nın verilmesi kaydedilmiştir. Bundan dolayı Sinan Paşa ve Mustafa Paşa bazı hususlarda anlaşmazlık yaşamışlardır. Örneğin, Mustafa Paşa'nın Mısır'dan dört bin asker tedarikine dair talebine Sinan Paşa beş yüz asker tedarik edileceği şeklinde karşılık vermiş, Mustafa Paşa'nın askerin iki yıllık zahire ve ulufelerinin peşin verilmesi talebine karşılık ise Sinan Paşa üç aylık zahire ve ulufe verilmesini kabul ederek, kalan kısmın seferde gösterilecek başarıya göre verileceğini belirtmiştir. Bu nedenle iki taraf da İstanbul'a ulak göndererek durumu bildirmek istemiştir. Mustafa Paşa'yı destekleyen beyler ittifak ederek Mısır beylerbeyinin sefer tedarikinde isteklerini karşılamadığını, bu nedenle ya Yemen fethinin Mısır beylerbeyine verilmesi ya da Mısır'ın serdar Mustafa Paşa'ya tevcih edilmesi gerektiğini arz etmişlerdir. Sinan Paşa ise gönderdiği arzında Mustafa Paşa'nın Mısır beylerbeyliği verilmedikçe Mısır beylerinin kendisine destek vermeyeceği, dolayısıyla serdarın sefer tedarikini göremeyeceği yönünde tahrik edildiğini kaydetmiştir. Ayrıca kendisinin Mustafa Paşa'nın bütün taleplerini istisnasız karşıladığını, serdarın, -kayınpederinin yaptırdığıKasr-1 Gavrî’ de her gün ziyafet verdiğini, hatta kendisini de davet ettiği bir ziyafette içtiği şerbetin zehirli olduğunu anladığı için tükürdügünü iddia etmiştir. Bunun yanı sıra Mustafa Paşa'nın Gavrî soyundan gelen- oğlunu Şam'dan getirterek Mısır tahtına geçireceğini, kendisinin de Yemen'i ele geçirerek burada sikke ve hutbe sahibi olarak sultan olmayı tasarladığını, hatta vezirlerin haremine dahi dil uzattığını kaydetmiştir. Âlî, tamamen yalan olarak nitelediği bu arzın aksine Mustafa Paşa'nın gayet edepli olduğunu, düşmanına dahi hakaretten imtina ettiğini belirterek Sinan Paşa'nın gerçekten mecliste içtiği şerbeti tükürdügünü, ancak hileyi anlayan Mustafa Paşa'nın kaseyi alarak içtiğini kaydetmiştir. Sinan Paşa'nın arzı rical üzerinde etkili 
olmuş ve serdarın katledilme emrini almak için uğraşmışlardır. Ancak Sultan Selim, lalası olması münasebetiyle eski hukukuna binaen katlini engellemiş ve durumun Şam'da teftiş edilmesi için emir göndermiştir. Yine de Sinan Paşa'nın arzının Sultan Selim ve rical üzerinde etkili olduğu, Mustafa Paşa'nın azledilerek Sinan Paşa'nın vezaretle Yemen'e serdar tayin edilmesinden anlaşılmaktadır. Azledilen Mustafa Paşa bir süre sonra İstanbul'a dönmüş, İstanbul'da Hoca Ataullah Efendi ve Musahib Celal Bey gibi devlet adamlarının yardımıyla affedilip altıncı vezir olarak divana girmiştir (Kütükoğlu 1979, 733; müellif Âlî, Yemen serdarlığı esnasında Mustafa Paşa'nın maiyetinde münşi, yani sırkatibi olarak bulunmuştur. Sinan Paşa, serdar tayin edildikten sonra Mustafa Paşa' dan esirgediği asker ve mühimmatı kendisi için tedarik etmiştir. Âlî 2009, cilt I, vr.431b-432b).

II. Selim döneminin en önemli olayı Kıbrıs Adası'nın fethedilmesidir. Âlî, Mustafa Paşa'nın Şam beylerbeyliği sırasında divan katibi olarak bulunmuş ve Paşa'nın henüz o dönemde dahi Kıbrıs ve Şirvan'ın fethini planladığını kaydetmiştir. Mustafa Paşa'nın bu arzusu bir süre sonra gerçek olmuş ve Kıbrıs'a düzenlenecek sefere serdar olarak tayin edilmiştir. 1570 yılının Ağustos ayında donanma Kıbrıs'a doğru hareket etmiştir. Bu seferde Mustafa Paşa'nın maiyetine Anadolu, Cezayir, Karaman, Sivas, Zulkadriye, Haleb beylerbeyleri ve Rumili'den Tirhala, Yanya, İlbasan ve Mora beyleri ile bunların maiyetinde bulunan sipahi ve zaimler katılmıştır. Ayrıca İstanbul'dan beş bin yeniçeri ile topçular ve bir miktar bölük halkı da sefere iştirak etmiştir. Kaptan Piyale Paşa da derya muhafazası amaciyla gönderilmiştir. Dört yüz parça gemiden oluşan donanma yaklaşık kırk günlük yolculuğun ardından Kıbrıs açıklarına varmıştır. İlk olarak Lefkoşa Kalesi’ne yönelen ordu, elli günlük kuşatmanın ardından oldukça muhkem olan bu kaleyi ele geçirmiştir. Lefkoşa Kalesi beylerinin kesik başları Girne Kalesi'ne gönderilince bunlar da korkudan amanla kaleyi teslim etmiş̧ir. Ordunun sonraki hedefi Mağusa Kalesi olmuştur. Yaklaşık elli günlük kuşatmanın ardından Mağusa da teslim olmuştur. Böylece Kıbrıs Adası, Mustafa Paşa'nın serdarlığında tamamen fethedilmiş ve beylerbeylik olarak Osmanlı topraklarına katılmıştır (Âlî 2009, cilt I, vr.444a-446a). Ancak Peçevi, Kıbrıs'ı fetheden Mustafa Paşa'nın, şehzadeler mücadelesinde Bayezid'e ihanet etmesi nedeniyle bu fetihten dolayı hak ettiği şan ve şöhreti elde edemediği iddiasındadır (Peçevî 1866, cilt I, 396).

Lala Mustafa Paşa'nın son büyük seferi ise İran'a yönelik düzenlenen sefer olmuştur. 1577 yılında Van beylerbeyi Hüsrev Paşa tarafından İstanbul'a gönderilen bir mektupta, Şah II. İsmail'in öldügü ve taht mücadelelerini değerlendirmek üzere İran'a sefer düzenlenmesinin gerektiği bildirilmiştir. Ortaya çıkan bu fırsatı değerlendirmek iki cephe üzerinden planlanan harekat için Erzurum'dan Lala Mustafa Paşa ve Bağdad tarafindan Sinan Paşa serasker tayin edilmiştir. Ancak Sinan Paşa askerin iyisinin Mustafa Paşa'ya verildiğini belirterek memnuniyetsizliğini bildirmiştir. Bunun üzerine Sokollu Mehmed Paşa'ya gönderilen hatt-1 hümayunda iki serdarın arasının bulunması emredilmiştir. İki Sokoloviç, Mehmed ve Mustafa Paşaların görüşmelerde ihtiyatlı olmasına karşın, Âlı̂’nin "gafil-i la-ya 'kıl”" olarak nitelediği Sinan Paşa inadından vazgeçmemiş ve sonuç olarak serdarlık 1578 yılında Mustafa Paşa' ya havale edilmiştir (Âlî 2009, cilt I, vr.483b; Lala Mustafa Paşa'nın İran serdarlığı ile ilgili olaylar Âlî tarafından Nusret-nâme isimli eserde kaleme alınmıştır. Bkz. Âlî 2014; müellif, Nushatü's-selatin isimli eserinin bir bölümünde ise Lala Mustafa Paşa'nın Şirvan serdarlığı sırasında yaptığı hataları kaydetmiştir. Âlî 2015, 377-382). Bu seferde emrine beş bin yeniçeri ile bölük halkı ve Diyarbekir, Erzurum, Zulkadriye, Haleb, Karaman beylerbeyleri ve bunların maiyetinde bulunan timarlı sipahiler ve zaimler katılmıştır (Âlî 2009, cilt I, vr.484a). İran serdarlığı sırasında Şirvan, Babülebvab, Tiflis ve Kars kaleleri fethedilmiştir (Hasan Bey-zade 2004, cilt II, 267 vd). Bu seferde Sokollu Mehmed Paşa'nın oğlu Hasan Paşa da emrinde bulunmuştur. Sefer devam ederken Sokollu Mehmed Paşa'nın şehit olması ve ardından sadrazam olan Ahmed Paşa'nın 
pasifliğinin yanı sıra üçüncü vezir Sinan Paşa'nın aleyhindeki faaliyetleri neticesinde Mustafa Paşa serdarlıktan azledilerek yerine Sinan Paşa atanmış ve Mustafa Paşa İstanbul'a dönmüştür (Peçevî 1866, cilt II, 62-63; Sinan Paşa, İran seferinde kendisinin serdar olması durumunda zafer kazanılacağını ve şahın ele geçirileceğini ve İran'ın fethinin tamamlanacağı iddiasında bulunarak padişahı ikna etmiştir. Hasan Bey-zade 2004, cilt II, 275; Âlî 2009, cilt I, vr.506b).

1580 yılı ortalarında Ahmed Paşa'nın ölmesi üzerine adet üzerine ikinci vezir olan Mustafa Paşa'nın sadrazam olması gerekmekteydi (Hasan Bey-zade 2004, cilt II, 281). Ancak Sinan Paşa taraftarlarının çalışmaları ve Mustafa Paşa'nın sadrazam olması durumunda muhalefetin işlerine sekte vuracağı şeklindeki sözlerinin padişahın kulağına gitmesi üzerine padişahın fikri değişmiştir (Âlî 2009, cilt I, vr.506a). Peçevî'nin naklettiğine göre Mustafa Paşa'nın sadrazamlıkta gözünün olmaması nedeniyle padişah mührü Sinan Paşa'ya gönderilmiştir. İçten içe sadrazamlık görevini bekleyen Mustafa Paşa bu duruma üzülmüsşür. Yaşlı paşa, Cuma günleri kadıaskerlerin sarayına gelmesi, divandan sonra çavuşların saraya kadar eşlik etmesi gibi protokol kurallarının yerine getirilmemesini padişaha şikâyet etmiş, padişah ise "gerçek sadrazam sensin, mühür seferde gayret etmesi için Sinan Paşa'ya gönderilmiştir” şeklinde bir hatt-1 hümayun göndererek Mustafa Paşa'nın gönlünü almaya çalışmıştır. Bundan sonra Mustafa Paşa eskisi gibi saygı görmüştür. Âlî, Mustafa Paşa'nın sadrazamlığa getirilmemesinin temel sebebini, Şehzade Selim ve Bayezid arasına fitne sokması ve Sultan Süleyman'ın şerefine gölge düşürmesi olarak açıklamıştır. Bu husus, Peçevî tarafindan da tekrarlanmıştır (Peçevî 1866, cilt II, 65-66; Âlî 2009, cilt I, vr.506a506b).

Peçevî'nin rivayetine göre paşa bir gece rüyasında Hz. Eyyub Ensari’nin ziyaretine varmış ve öldükten sonra defnedilmesi için bir yer bulduktan sonra mütevelliyle anlaşarak parasını vermiştir. Sevinç içinde çiftliğine giden paşa, üvey oğulları olan Ferhad Paşazadelerle sohbet ederken "on yedi günlük ömrümüz kaldı" demiştir. Çocukları bunu bunamasına yorsalar da Paşa on yedinci günü evinin bahçesindeyken ölümü hissetmiş ve hemen sarayına girerek orada vefat etmiştir. Mustafa Paşa, 7 Ağustos 1580 tarihinde öldüğünde yetmiş yaşını geçmiştir (Peçevî 1866, cilt I, 442; cilt II, 20; Âlî 2009, cilt I, vr.506b).

Mustafa Paşa'nın görev yaptığı hemen her yerde hayır faaliyetlerinde bulunduğu anlaşılmaktadır. O, Erzurum'da bir cami ve vakıf, Karaman'ın Ilgın kasabasında bir cami ve imaret, Şam'da üç yüz altmış odalı bir kervansaray, Kudüs yakınlarında bir cami ve imaret ile Mekke ve Medine'de bazı hayır eserleri vücuda getirmiştir (Âlî 2009, cilt I, vr.507a). Kıbrıs'ta Mağusa'nın fethinden sonra katedralden camiye çevrilen yapı kendi ismi ile anılmaktadır.

Mustafa Paşa, çaşnigir olarak görev yaparken, Memluk sultanı Gavri'nin oğlu Mehmed (Muhammed) Bey'in vefatından sonra tek kalan varisi olan kızı ile evlenmiştir. Bu evliliğe, o dönemde kapıcılar kethüdası olan Mustafa Paşa'nın ağabeyi Hüsrev Paşa aracılık etmiştir. Mısır, Şam ve Haleb gibi yerlerde oldukça yüksek gelire sahip köylere sahip olan Mustafa Paşa'nın yılda on bin filoriden fazla gelir elde ettiğini Âlî kaydetmiştir. Mustafa Paşa'nın Kıbrıs serdarlığı sırasında eşi vefat etmiştir. Bir süre sonra Sultan Süleyman'ın oğlu Şehzade Mehmed'in kızı Hüma Sultan ile evlendirilen Mustafa Paşa böylece hem Osmanlı hem de Memluk hanedanına damat olmuştur. Paşanın çocukları ise kendisi gibi uzun ömürlü olmamıştır. Âlî’nin Künhü'lAhbar'ı kaleme aldığı dönemde yalnızca Hüma Sultan'dan olan Abdülbaki Bey hayattadır (Âlî 2009, cilt I, vr.507a).

Âlî, uzun yıllar yanında kaldığı Mustafa Paşa'yı cesur, cömert, arslan yaratılışlı bir savaşçı, hiddetli ve "ateşli" bir kişilik olarak tanımlayarak, adeta kendisini himaye eden Paşa'ya borcunu ödemek istemiştir (Âlî 2009, cilt I, vr.451b, vr.506a). 


\section{Lala Mustafa Paşazade Mehmed Paşa}

Mustafa Paşa'nın Memluk sultanı Kansu Gavri'nin kızından olan oğludur. Cesaretiyle ün salan Mehmed Paşa birkaç sancak yönettikten sonra önce Zulkadriye, ardından 1573 yılında Haleb beylerbeyi olmuş ve otuz yaşındayken Haleb'de vefat etmiştir. Âlî'ye göre gözü tok ve merhametli olan Mehmed Paşa, babasının zoruyla kabul ettiği beylerbeyliğin zor bir görev olduğunu zikretmiş ve kabul etmesinden dolayı pişman olduğunu belirtmiştir. Hâkim olduğu yerlerde reayayı koruyan Mehmed Paşa, reayadan gelen şikâyetleri dikkate alarak gereken cezaları uygulamıştır. Mahlûl kalan timarların parayla satıldığı bir dönemde Mehmed Paşa bunları ne iç oğlanları için ayırmış ne de parayla satmıştır, timarı ilk talep eden kişiye tevcih etmiştir. Âlî, vefat ettiğinde yalnızca bin altın sikkesi tespit edilen Mehmed Paşa'nın ardından Haleb'de yas tutulduğunu belirtmiştir (Jorga 2005, cilt III, 151; Âlî 2009, cilt I, vr.453a).

Âlî, eserinin devamında Mehmed Paşa'nın Lala Mustafa Paşa'nın akrabalarından olduğunu kaydetmiş ve bu arada Erzurum beylerbeyi olduğunu da belirtmiştir (Âlî 2009, cilt I, vr.508a). Sinan Paşa'nın İran serdarlığında Mehmed Paşa bir süre sonra Erzurum beylerbeyliğinden azledilmiştir (Âlî 2009, cilt I, vr.511a). Mehmed Paşa'nın Cigalazade'nin serdarlığı esnasında Rum eyaletine beylerbeyi olduğunu Âlî kaydetmiştir. Müellif, burada da Mehmed Paşa'yı Lala Mustafa Paşa'nın akrabası olarak göstermiştir (Âlî 2009, cilt I, vr.534a).

\section{Mustafa Pașa}

Sokollu Mehmed Paşa'nın küçük kardeşi yerine geçerek İstanbul'a gelen amcazadesidir. Şehzade Mehmed'in vefat ettiği 1543 yılında saraydaki küçük odalardan hazine odasına geçmiş ve bir süre berberbaşılık yaptıktan sonra Elkas Mirza üzerine yapılan sefere padişahın maiyetinde katılmış ve yedi sene sultanın hizmetinde bulunmuştur. Bu seferden sonra Sokollu Mehmed Paşa Rumili beylerbeyliğine tayin edilince Mustafa Ağa da otuz üç akçe ulufeyle saraydan taşra çıkarak sipahi olmuş ve bir süre sonra da Bosna'da cizye toplamaya memur edilmiştir (Nahîfî Mehmed Efendi 2019, 168-172; Abdurrahman Şeref 1330, 265; Mehmed Süreyya ise Mustafa Paşa'nın Enderun'dan çıktıktan sonra küçük mirahur ve daha sonra çakırcıbaşı olduğunu, ardından beylerbeyi olduğunu kaydetmiştir. Mehmed Süreyya 1996, cilt IV, 1181).

Bir süre cizyedar olarak hizmet veren Mustafa, Sultan Süleyman'ın 1553 yılında düzenlediği İran seferi sırasında çaşnigir olmuş ve iki yıla yakın bu görevde kalmıştır. Nisan $1555^{\prime}$ te altmış bin akçe gelir ile Tımışvar defterdarlığına getirilen Mustafa, beş yıla yakın bir süre sürdürdüğü bu görevin ardından Mart 1560'ta Fülek sancakbeyi olmuştur. Bu dönemde Sokollu Mehmed Paşa da üçüncü vezirlik makamında bulunmaktadır (Nahîfî Mehmed Efendi 2019, 172-175).

Mustafa Paşa'nın Fülek'ten sonraki görevi Klis sancakbeyliğidir (Nahîfî Mehmed Efendi 2019, 202). Burada kısa süre görev yapan Mustafa Paşa'nın görev yeri, Sokollu Mehmed Paşa'nın ikinci vezir bulunduğu 1563 yılı yaz aylarında Segedin'e nakledilmiştir (Nahîfî Mehmed Efendi 2019, 238). Bir süre sonra Hersek sancağı mahlul kalmış ve buraya da bir sancakbeyi tayini gerekmiştir. O dönem sadrazam olan Semiz Ali Paşa, Hersek sancağının kendi akrabası olan Tor Ali Bey'e tevcih edilmesi yönünde arzda bulunmuştur. Sultan Süleyman, Tor Ali'nin kim olduğunu sorduğunda ise yarar kullarından biri olduğunu belirtmiştir. Ancak Sultan, Segedin sancağını adalet ve şecaatle ünlenmiş olan Segedin beyi Mustafa'ya verdiğini bildirmiştir. Şefik Efendi, olayın bu şekilde neticelenmesinde ikinci vezir Mehmed Paşa'nın rolünün olduğunu vurgular ki, bu durum Sokollu Mehmed Paşa'nın henüz ikinci vezirken dahi padişah üzerindeki etkisinin sadrazamdan üstün olduğunu göstermektedir (Nahîfî Mehmed Efendi 2019, 254). Mustafa Paşa'nın Segedin beyliği de kısa süreli olmuş ve beş hafta bu görevde kaldıktan sonra 26 Eylül 1563’te Bosna sancağı kendisine tevcih edilmiştir (Nahîfî Mehmed Efendi 2019, 257, 260). 
Bosna'da sancakbeyi iken Krupa'nın da dahil olduğu birkaç kale ve palanka fethetmiştir (Hammer 1332, cilt VI, 133). Sultan Süleyman'ın Sigetvar seferi sırasında Arslan Paşa'nın yerine Budin beylerbeyi olarak atanmıştır. Peçevî bu atamayı sıradan ifadelerle aktarırken, Hasan Beyzade ve Selanikî Mustafa bunda Sokollu Mehmed Paşa'nın rolünü açıklamışlardır. Hasan Beyzade'nin aktardığına göre Sokollu Mehmed Paşa, Arslan Paşa'yı sulhe aykırı hareketleriyle düşmanı harekete geçirmekle suçlamış ve "garaz-l derûnîsini izhar eylemiş"tir. Beyzade’ye göre yiğitlikte Rüstem'e benzeyen Arslan Paşa için "muhannes (korkak)" olduğu yolunda arzlarda bulunan Mehmed Paşa, Avusturya'nın harekete geçmesinde Arslan Paşa'nın rolü olduğunu da belirterek padişahtan katlini talep etmiştir. Sultan Süleyman'ın fermanıyla Arslan Paşa katledilmiş ve yerine Mehmed Paşa'nın amcazadesi Mustafa Paşa Budin'e beylerbeyi olmuştur (Selanikî 1999, 25-27; Hasan Bey-zade 2004, cilt II, 144-5; Peçevî, bu konuyu aktarırken Mustafa Paşa'nın Sokollu Mehmed Paşa'nın kardeşinin oğlu olduğunu belirtmiştir. Ancak daha sonra Mustafa Paşa'nın amcazadesi olduğunu kaydetmiştir. Peçevî 1866, cilt I, 416; cilt II, 7).

Mustafa Paşa, Sultan Selim devrinde vezirliğe yükselmiştir. On üç yıl kadar kaldığı Budin'de sayısız hizmeti geçmiştir. Peçevî'nin cömert, eli açık ve iyiliksever olarak tanımladığı Mustafa Paşa, Budin'de cami, medrese, han ve imaretler yaptırmıştır. Budin'de dış sur, baruthane ve kaleye bazı kuleler ekletmiş, Sigetvar ve İstolni Belgrad kalelerine de büyük burçlar yaptırmıştır. Yetimlere ve bekârlara durumlarına göre çeyiz vererek evlendirmiş ve geçimleri için dirlik tahsis etmiştir (Mustafa Paşa'nın Budin'de ve imparatorluğun diğer yerlerinde yaptırdığı hayır eserleri için bkz. Kaldy-Nagy 1990, cilt LIV/210, 649-663; ayrıca Kaçan Erdoğan 2016, 67-116). İstanbul'daki iktidar çekişmelerinin sonucu olarak 1579 yılında Budin saray ve barut mahzenlerine yıldırım düşmesi bahane edilerek suçlu bulunmuş ve gizlice gönderilen mirahur-1 kebir Ferhad Ağa tarafından katledilmiştir (Peçevî 1866, cilt II, 26-28). Hasan Beyzade, Mustafa Paşa'nın serhadlerde sevildiğini ve halk arasında hayır sahibi olarak yâd edildiğini belirtmiştir (Hasan Bey-zade 2004, cilt II, 256).

\section{Ferhad Paşa}

Sokollu Mehmed Paşa'nın amcasının oğlu ve tarihçi Peçevî İbrahim Efendi'nin dayısı (Peçevî 1866, cilt I, 454) olan Ferhad Paşa'nın tespit edilebilen ilk görevi ulufecibaş11ıtır. Sigetvar seferine padişahın maiyetinde katılan ve Peçuy sahrasındaki alay töreninde Sokollu Mehmed Paşa'nın bayrağı altında bulunan (Selanikî 1999, 27) Ferhad Bey, 1566 yılında Klis sancakbeyi olmuştur (Koric 2015, 47, 51). Kıbrıs'ın fethinin ardından Osmanlı ve ittifak donanmalarının deniz savaşına odaklandığı günlerde Klis sancakbeyi Ferhad Bey de harekete geçmiş, Dalmaçya taraflarında Venedik'e tabi birçok kaleyi fethederek sancağın sınırlarını genişletmiştir (Koric 2015, 58-86). İki devlet arasında barışın sağlanmasının ardından sınır tespiti işi de Ferhad Bey tarafından yürütülmüştür (Peçevî 1866, cilt I, 454; Doğan 2017, 150).

Klis Sancă̆ı'nı başarıyla yöneten ve Dalmaçya'da Venedik topraklarına yönelik olarak önemli faaliyetlerde bulunan Ferhad Bey, amcazadesi Sokollu Mehmed Paşa'nın da desteğiyle 1573 yılında Bosna sancakbeyliğine getirilmiştir (Koric 2015, 99; Sigetvar seferi sırasında Şam'da Lala Mustafa Paşa'nın divan katipliğini yapan tarihçi Mustafa Âlî, Sokollu Mehmed Paşa'ya ithaf ettiği ve Sigetvar seferi ile II. Selim'in cülusunu anlattı̆g 1 Heft Meclis isimli eser sayesinde H.978/M.1570-71'de yine Sokoloviç ailesinden olan Ferhad Bey'in divan katipliğine atanmıştır. Müellif, Klis ve Bosna sancakbeylikleri sırasında Ferhad Bey'in maiyetinde kâtip olarak bulunmuştur. Âlî 2000, cilt I, 10; Âlî 2014, XXIII; müellif, Zübtetü't-tevarih isimli eserini de Ferhad Bey'in isteğiyle telif etmiş ve 1575 yılında tamamlamıştır. Âlî 2000, cilt I, 13). Bosna'da da pek çok fütuhatta bulunan Ferhad Bey, Senjli Uskoklara yönelik saldırılarından birinde Hırvat generalini oğluyla birlikte ele geçirerek Sultan III. Murad'a göndermiştir. Sultan, esirleri otuz bin 
altın karşılığında serbest bırakmış ve bu altınlar ile Banyaluka'da Ferhad Paşa adına cami yapılmıştır. 1580 yılında Bosna Sancağı, Rumeli ve Budin eyaletlerinden bazı sancakların da katılımıyla eyalet olarak yapılandırılmış ve Sokoloviç Ferhad Bey, "paşa" unvanı verilerek Bosna Eyaleti'nin ilk beylerbeyi olarak tayin edilmiştir (Oruç 2005, 253; Koric 2015, 137). Mehmed Giray Han'ın isyanını bastırması için Haziran 1584-Ekim 1585 arasında Kefe beylerbeyi olarak görevlendirilen Ferhad Paşa, bu kıs süreli ara dışında 1588 yılına kadar Bosna beylerbeyi olarak görev yapmıştır (Koric 2015, 156-170). Kefe'de rahatsızlandığı sırada Ferhad Paşa'nın adamlarından biri terekesini kaydetmiş, bu terekede üç yüz kölesi ve diğer malları kayıt altına alınmıştır (Peçevî 1866, cilt I, 454). 1588 yılının Haziran ayında Bosna beylerbeyliğinden azledilen Ferhad Paşa, birkaç ay sonra Budin beylerbeyliğine tayin edilmiştir (Selanikî 1999, 202; Koric 2015, 186).

Ferhad Paşa, 1590 yılının Eylül ayında Budin beylerbeyi olarak görev yaptığı sırada şehit edilmiştir. O dönemde vezir Sinan Paşa'nın akrabalarından olan Beyza-füruş Sinan Paşa Tımışvar beylerbeyi idi. Budin'i akrabasına vermek isteyen vezir Sinan Paşa, İstanbul'a gelen Budin azaplar ağası Rıdvan Çavuş'a "beylerbeyiniz olan potur sağ mıdır" diyerek durumu sormuştur. Vezirin niyetini anlayan Rıdvan Çavuş, Ferhad Paşa'nın iki yüzlü olduğunu ve Budin'i harap ettiğini belirterek Budin'i Ferhad Paşa'nın elinden kurtarmasını istemiştir. Vezir ise karşılık olarak Ferhad Paşa'nın işinin bir kurşun ile bitirilmesini ima eden sözler sarf etmiştir. Ayrıca kendi adamlarından olan Estergon ve Hatvan beyleri ile Budin alaybeyine de mektuplar göndererek Ferhad Paşa aleyhinde kışkırtmıştır. Durumu anlayan Budin hazine defterdarı, Ferhad Paşa'yı isyan çıkacağı konusunda uyarmış ve ava çıkma bahanesiyle bütün asilerin ortadan kaldırılmasını teklif etmiştir. Ancak kibirli ve başına buyruk bir kişiliğe sahip olan Ferhad Paşa, görünürde isyana dair bir emare olmadığını belirterek hazinedarın işiyle meşgul olmasını emretmiştir. Bir süre sonra Peşte yakasında bulunan askerler ayaklanmış ve Budin'den bazı askerler de bunlara katılmıştır. Yüz kadar asker paşa sarayını basmış ve Ferhad Paşa'yı şehit etmiştir. Âlî, durumu o dönemde Budin'de bulunan bir zaimden soruşturmuştur. Zaim, Ferhad Paşa'nın kibrinden ötürü beylerin görüşlerini dikkate almadığını ve bunun huzursuzluğa neden olduğunu aktarmıştır. Zahire kıtlığını ve ulufelerin azlığını bahane eden askerlerin isyan ettiğini ve paşayı öldürdüğünü söylemiştir. Budin eyaleti bir süre sonra Beyza-füruş Sinan Paşa'ya tevcih edilmiştir (Âlî 2009, cilt I, vr.551a-552a).

Selanikî ise olayı farklı bir şekilde aktarmıştır. Ona göre, serhadde yerleşen eşkıya o dönemde tamamen kontrolden çıkmış ve Budin'de kıtlık yaşanınca bunu bahane ederek isyan etmiştir. Budin ve Peşte tarafındaki eşkıyalar ittifak halinde Ferhad Paşa ve defterdar Bali Efendi'ye saldırarak altı aylık mevacibini zorla tahsil etmişlerdir. Ancak eşkıyanın zulmü bununla sona ermemiştir. Bir kıst mevacibin daha peşin verilmesini talep eden eşkıya Ferhad Paşa'yı şehit etmiş, defterdar ise kaçarak canını kurtarmıştır. Ancak müellif, Âlî'den farklı olarak haberlerin İstanbul'a ulaşması üzerine Budin beylerbeyliğinin Tımışvar beylerbeyi Mustafa Paşa'ya tevcih edildiğini belirtmiştir (Selanikî 1999, 225). Bu isyanda başı çeken otuz beş kişi, olayı soruşturmak için gönderilen çavuş ve müteferrika tarafından tespit edilerek idam edilmiştir (Selanikî 1999, 233).

Peçevî, Ferhad Paşa'nın vasıflarını övmektedir. Ona göre Ferhad Paşa'nın edep, terbiye, ağırbaşlılık ve alçak gönüllülüğü din adamlarından dahi yüksektir. Oturduğu zaman dizleri üzerine çöken Ferhad Paşa, yalnızca nişancılık görevinde bulunurken bağdaş kurarak oturmuştur. Konuşma sanatını iyi bilen Paşa'nın sohbetleri beğeniyle takip edilmekteydi. Doğru konuşan ve abartmayı sevmeyen Ferhad Paşa, dinen yasak olan hiçbir duruma karşı çıkmamıştır. Peçevî, özellikle sınır boyunda düşmanla yaşanan bütün sorunları yazılı bir şekilde çözmeye çalışmıştır. 
Müellife göre, Avusturya ile yapılan barış görüşmelerinde Ferhad Paşa gibi iş bilir devlet adamlarının görüşlerine başvurulması durumunda, yapılacak barışta elde edilecek avantajlar, Kanuni Sultan Süleyman döneminin bile üzerinde olacaktı (Peçevî 1866, cilt II, 433-434).

\section{Derviş Paşa}

Tarihçi Peçevî’nin dayısıdır. Sokollu Mehmed Paşa'nın amcazadesi ve Budin’de şehit düşen Ferhad Paşa'nın biraderidir. Son derece cesur ve binicilikte ustaydı. Peçevî'nin ifadesine göre, zamanın Şam ve Halep binicileri Derviş Paşa'dan ders almış olmakla övünürlerdi. Oldukça cömert bir insan olan Paşa için "el arkası yerde" denmekteydi. Sokollu ailesinde cömertlik Budin beylerbeyi Mustafa Paşa ve Derviş Paşa'da son raddeye erişmiştir. Peçevî, bütün kullarına yıllık ödenekleri birkaç kez verdiğini belirtmektedir (Peçevî 1866, cilt II, 41-42). Nusretname'ye göre 1579'daki şark seferinde Diyarbekir beylerbeyi olarak bulunmuştur (Âlî 2014, 38, 88).

\section{Sokollu Mehmed Paşazade Hasan Paşa}

Sokollu Mehmed Paşa'nın ilk eşinden olan oğlu Hasan Paşa'nın adı kroniklerde ilk kez Sultan Süleyman'ın Sigetvar seferinde geçmektedir. Selanikî'nin nakline göre, ordu Peçuy sahrasına geldiğinde Sultan Süleyman bütün vezirlerden alaylarını göstermesini istemiş ve bu sırada sadrazam Sokollu Mehmed Paşa'nın oğulları Hasan Paşa ile Kurd Bey maiyetleriyle birlikte padişahın huzurundan geçmişlerdir (Selanikî 1999, 27). Arşiv kayıtlarına göre Hasan Paşa'nın tespit edilebilen ilk görevi 1571 yılında tayin edildiği Bosna sancakbeyliğidir. Bosna'da bir y1l kalan Hasan Paşa 1572 yılında Haleb, 1573 yılında ise Diyarbekir beylerbeyliğine tayin edilmiştir (Gökbilgin'e göre 1561 yılında Bosna'ya tayin edildiyse de bu bilginin doğruluğu tartışmalıdır. Gökbilgin 1979b, cilt V/1, 325; Afyoncu 2009b, cilt XXXVII, 366).

Hasan Paşa, Diyarbakır beylerbeyi iken, bahar mevsiminde sefere çıkacak donanma için tüfekçi ve piyade askeri hazırlaması için emir almıştır. 1576 yılına kadar bu görevde kaldığı anlaşılan Hasan Paşa, daha sonra Erzurum beylerbeyi olmuştur. Kısa bir süre sonra ise 1577 y1lı yaz aylarında Dürzi şeyh ve reislerinin isyan ettiği Şam'a beylerbeyi olarak tayin edilirken, acil bir şekilde görev yerine gitmesine dair ferman gelmiştir (Gökbilgin 1979b, cilt V/1, 325).

1579 yılında, babasının şehadetinden hemen önce Hasan Paşa'nın Şam beylerbeyi iken İran üzerine yapılacak sefer için askeriyle birlikte Erzurum'a gitmesi emredilmiştir (Selanikî 1999, 124; Âlî 2009, cilt I, vr.499a). Hasan Paşa sefer hazırlıklarını tamamlayıp yola koyulmak üzere olduğu sırada babasından bir mektup gelmiştir. Mehmed Paşa, oğluna Tiflis'e gitmesi için ferman geleceğini ve buna karşı çıkmamasını, hazırlığını iyi yaparak bunu yükselmesi için bir fırsat olarak görmesini tenbih etmiştir (Peçevî 1866, cilt II, 57; Âlî 2009, cilt I, vr.505a; Âlî 2014, 296297). Âlî ise Tiflis'in fethinin gecikmesi üzerine askerlerin serdara mektup göndererek başlarında olmadığ 1 sürece bu zor işi başaramayacaklarını yazdıklarını, bunun üzerine Sokollu Mehmed Paşa'nın "nur-ı didesi ve unfüvan-ı şebabı halinde kemal-i cah ü celaletle iktifa ve emsalinin matbu u pesendidesi civan-merd-i rüzgar mihver-i daire-i ceng ü peykar" olan oğlu Şam beylerbeyi Hasan Paşa'nın sipehsalar olarak gönderildiğini belirtmektedir (Âlî 2009, cilt I, vr.504b; müellif, Hasan Paşa'nın serdar Lala Mustafa Paşa maiyetine ulaştığında Hasan Paşa'ya bir kaside sunduğunu belirtmiştir. Âlî, bu kasidede Hasan Paşa'nın vasıflarını övmektedir. Âlî 2014, 252-253). Hasan Paşa 1579 yılının Mayıs ayı ortalarında Anadolu beylerbeyi Cafer Paşa ile birlikte Erzurum'dan hareket ederek Erzincan'a varmıştır (Âlî 2014, 255). Serdarlığın Lala Mustafa Paşa'dan alınıp Sinan Paşa'ya verilmesinin ardından onun maiyetine katılmıştır (Âlî 2009, cilt I, vr.507b). Âlî’nin cesaretinin atadan miras olduğunu zikrettiği Hasan Paşa, bu sefer sırasında Gürcistan içlerine kadar girerek çok sayıda esir ve ganimet elde etmiştir (Peçevî 1866, cilt II, 88; Âlî 2009, cilt I, vr.528b; Âlî 2014, 292). 
1580 yllında tekrar Diyarbekir beylerbeyliğine tayin edilmişse de padişahın hatt-1 hümayunuyla Şam'da kalmıştır. Aynı yılın sonlarına doğru görev yeri Bağdad'a nakledilmiş, kısa süre sonra tekrar Şam'a dönmüştür (Afyoncu 2009b, 366). Selanikî'nin kaydına göre 1582'de Şehzade Mehmed'in sünnet düğününe Şam beylerbeyi olarak iştirak etmiştir (Selanikî 1999, 134). İran seferinin devamında kendisine ihtiyaç duyulması üzerine tekrar sefere iştirak etmiş ve Revan'ın fethi ile Ağrı civarında orduya saldırılar düzenleyen Kara Veli isimli eşkıyanın ele geçirilmesinde hizmetleri görülmüştür (Gökbilgin 1979b, cilt V/1, 326). Hasan Paşa'nın İran seferi devam ederken Eylül 1588'de Haleb beylerbeyi olduğu anlaşılmaktadır. Ordu Gence'ye geldiği sırada vezir Cafer Paşa vefat etmiş, ertesi günkü divanda Anadolu beylerbeyi Hadım Hasan Paşa Şirvan muhafızlığına gitmiş, onun yerine Sokolluzade Hasan Paşa geçmiştir (Selanikî 1999, 207-208). Burada kısa süre kalan Hasan Paşa, daha sonra Erzurum beylerbeyliğine getirilmiştir.

1588 yılı başında İran seferi serdarı Ferhad Paşa'nın Revan ve Nahcivan üzerine gelen Kızılbaş askerinin üzerine gitmesini emrettiği Hasan Paşa, kış mevsimini bahane ederek askerin kendisine itaat etmeyeceğini, bu durumun ise düşman için fursat olacağını söylemiştir. Ferhad Paşa bu cevap üzerine hiddetlenerek Hasan Paşa'yı azletmiş ve yerine Hızır Paşa'yı tayin etmiştir. Beylerbeylikten azledilmesine kederlenen Hasan Paşa ise İstanbul'a gelerek affedilmesi ricasında bulunmuş, ancak ortaya çıkan durum padişah tarafından hoş karşılanmamıştır (Selanikî 1999, 200). Ancak padişahın kini uzun sürmemiş ve Hasan Paşa aynı yıl içinde yine Şam beylerbeyi olmuş, ardından Anadolu beylerbeyliğine getirilmiştir. Hasan Paşa, 1591 y1lında sadrazam Sinan Paşa'nın Ayan (Sapanca) Gölü'nü İznik körfezine bağlama çalışmalarına mübaşir olarak tayin edilmiş ve kendisine bu iş için gerekli masraf ve malzemenin temin edilmesi emredilmiştir (Selanikî 1999, 233; Afyoncu 2009b, 367).

Doğuda İran ile barışın sağlanmasının ardından Hasan Paşa, 1591 yılında Anadolu beylerbeyliğinden Rumili beylerbeyliğine tayin edilmiştir. Rumili beylerbeyi (Apostol) Hasan Paşa, yeniçeri ağasıyken kul taifesinin işlerini görmek için paralarını almış ancak daha sonra bu işleri savsaklamıştır. Yeniçerilerin şikâyetleri padişaha kadar ulaşmış ve bunun üzerine önce paşanın adamları hapsedilmiş, ardından kendisi de Çorlu'da ikamet etmek üzere azledilmiştir. Boşalan Rumili eyaleti ise Sokolluzade Hasan Paşa'ya tevcih edilmiştir (Selanikî 1999, 236).

$\mathrm{Bu}$ dönemde Bosna sınırında yaşanan sorunlar üzerine Rumili beylerbeyi Hasan Paşa Bosna muhafazasına gönderilmiştir. Ancak bir süre sonra Sinan Paşa tekrar sadrazamlığa getirilmiş ve ilk iş olarak Âlî̀nin tabiriyle "ebter (hayırsız)" oğlunu Rumili'ye tayin etmiş ve Bosna'ya varmak üzere olan Hasan Paşa'yı geri çağırmıştır (Âlî 2009, cilt I, vr.555a).

1593 y1lında Budin beylerbeyi Sinan Paşazade Mehmed Paşa azledildikten sonra Sokolluzade Hasan Paşa'ya vezaret verilerek Budin muhafizlığı ile görevlendirilmiştir (Selanikî 1999, 304). Aynı yıl içinde Avusturya'nın İstolni Belgrad'ı kuşatması üzerine Budin'de bulunan Hasan Paşa civardaki beş sancağın askerini toplayarak yaklaşık yirmi bin asker ile yardıma gitmiştir. Hasan Paşa'nın geldiği haberini alan Avusturyalılar ise kuşatmayı kaldırarak iki fersah (yaklaşık $11 \mathrm{~km}$ ) uzaklıkta bir dağ dibine yerleşmiştir. Osmanlı kuvvetleri de İstolni Belgrad yakınında bir tepeye konmuş ve burada toplanan divanda ne yapılacağ tartışılmıştır. Savaş tecrübesi olmayan bir kısım asker hemen düşman üzerine hücum edilmesini savunurken, tecrübeli askerler ise süvarilerin düşman üzerine gönderilmesini, düşman kaçarsa kovalanmasını, saldırırsa bütün ordunun kale etrafına çekilerek kaledeki toplarla ordu kuvvetinin muhafaza edilmesini teklif etmiştir. Sonuçta savaş taraftarları galip gelmiş ve yapılan muharebede, Hasan Paşa'nın hazinedarı, içoğlanları, silahtarı dâhil olmak üzere altı-yedi bin Osmanlı askeri ölmüş, kalanlar ise İstolni Belgrad ve Budin tarafına firar etmiştir. Hasan Paşa ise meydanda kimse kalmayıncaya dek direnmiş, koltuk 
altından küçük bir kurşun yarası almıştır. Kurşun sıyırmasına rağmen, fişeğin ateşi paşanın entarisini tutuşturmuş ve bu nedenle paşanın vücudunun bir kısmı ağır şekilde yanmıştır (Peçevî 1866, cilt II, 137; Selanikî 1999, 339; Âlî 2009, cilt I, vr.557b-558b; Katip Çelebi 2016, 29-30).

Âlî, tedbirsiz bir şekilde düşman üzerine giden serdar Sinan Paşa'nın kışlamak üzere Belgrad'a çekildiği sırada Budin beylerbeyi Hasan Paşa'yı İstolni Belgrad'a gönderdiğini belirtmiştir. Burada düşman askerine başta üstünlük sağlayan Osmanlı kuvvetleri, daha sonra gelen kuvvetlere karşı direnememiş ve Budin beylerinden bir kısmı ile yeniçeri ağası şehit düşmüştür. Müellif, Sinan Paşa'nın oğlu ile birlikte İstolni Belgrad'a yardıma yetişebileceğini ancak "muhannesliği (korkaklı̆gl)" nedeniyle gitmediğini belirtmiştir. İstanbul'a yazdığı arzda da bütün suçun Hasan Paşa'ya ait olduğunu, böyle bir saldırıya gitmemesi gerekirken gittiğini bildirmiş, kendinin ve oğlunun ise cesur bir şekilde savaştığını kaydetmiştir (Âlî 2009, cilt I, vr.557a-557b).

Ertesi sene Avusturyalılar Hatvan üzerine yürüyerek ilk olarak Novigrad'1 kuşatmıştır. İstolni Belgrad'da yaralanan Hasan Paşa yardıma gidememiş ve Karaferyeli Mehmed Bey kaleyi vire ile teslim ederek ahali ile birlikte Budin'e gitmiştir. İstolni Belgrad'daki divanda savaş taraftarlarının başını çeken Mehmed Bey, kaleyi teslim etmesi bahane edilerek Hasan Paşa tarafından idam ettirilmiştir (Peçevî 1866, cilt II, 141).

1594 yılı başlarında kapıcıbaşı Veli Ağa yanına verilen yirmi kapıcı ile serhaddi denetlemek ve bazı gizli emirleri yerine getirmek için Budin'e gönderilmiştir. Ancak Budin'deki askerler, Veli Ağa'nın İstolni Belgrad ve Hatvan'daki mağlubiyetlerden dolayı Hasan Paşa için geldiğini düşünerek, Budin'deki kale muhafizlarının terk ettiği kalelerden beylerbeyinin sorumlu tutulmaması gerektiği, ayrıca sınırdaki sancakbeylerinin üç ayda bir değiştirildiğini ve sancakbeylerinin servetlerini asker toplamak yerine rüşvet dağıtmak için harcadıklarını, bu durumun ise sınırdaki beylerin asker beslemesine imkân vermediğini belirtmişlerdir. Veli Ağa aldığı bu cevaplar ile İstanbul'a dönmüştür (Selanikî 1999, 359).

Seferin devamında Yanıkkale üzerine kuşatmaya giden serdar Sinan Paşa, oğlu ile Hasan Paşa'nın görev yerlerini değiştirmiştir. Buna göre oğlu Budin beylerbeyliğine, Hasan Paşa ise Rumili beylerbeyliğine getirilmiştir (Peçevî 1866, cilt II, 146; Âlî, Ağustos 1593'te Hasan Paşa'y1 Rumili beylerbeyi olarak göstermektedir. Âlî 2009, cilt I, vr.561a). Selanikî ise 1594 y1lı başındaki tayinlerde Hasan Paşa'nın Rumili'ye, Mehmed Paşa'nın ise Budin'e tekrar tayin edildiğini kaydetmiştir (Selanikî 1999, 390). Yanıkkale'nin fethedilmesinin ardından kuşatılan Komran kalesinde bulunan askerler kaleyi Rumili beylerbeyi Hasan Paşa'ya vire ile teslim etmeye karar vermiştir. Ancak Sinan Paşa, "keferenün maksudları Rumili emirül-ümerasına teslimdür, benüm oğluma teslim eylesünler" diyerek oğlu ile Hasan Paşa'nın yerlerini değiştirmiştir (Peçevî ve ondan naklen Katip Çelebi, bunun sınırların durumunu bilmeyenler arasında dolaşan bir söylenti olduğunu, böyle bir teklifi serdar reddetse bile askerlerin baskısı ile kabul edileceğini kaydetmiştir. Peçevî 1866, cilt II, 155; Katip Çelebi 2016, 58). Meydana gelen bu gelişmeler üzerine Komran kalesi teslim olmaktan vazgeçmiş ve kalenin fethi bir yıl gecikmiştir. Bu seferin dönüşünde serdar Sinan Paşa Belgrad'da kışlamış, oğlu Mehmed Paşa'yı Budin, Hasan Paşa'yı ise İstolni Belgrad muhafazasına göndermiştir (Hasan Bey-zade 2004, cilt II, 396-397; Âlî 2009, cilt I, vr.563a).

1595 yılı başlarında isyan eden Eflak beyleri, üzerlerine gelen Maraş beylerbeyi serdar Mustafa Paşa'yı mağlup etmiş ve bu nedenle Ruscuk, Eflaklıların eline geçmiştir. Bunun üzerine Hasan Paşa, Eflak üzerine serdar tayin edilmiştir (Selanikî 1999, 451). Hasan Paşa bir süre sonra tekrar Rumili beylerbeyliğine getirilmiş, Sinan Paşazade Mehmed Paşa ise Budin muhafızlığına gönderilmiştir (Selanikî 1999, 457). Aynı yılın Temmuz aylarında Hasan Paşa, Vidin kalesine yürüyen ve Tuna'dan gemilerle desteklenen düşman ordusuna karşı harekete geçmiş, kara ve 
nehirde meydana gelen mücadele Osmanlılar lehine sonuçlanmıştır. Bu savaşta çok sayıda esir ve ganimet elde edilmiştir. Ele geçen esirlerin bir kısmı İstanbul'a gönderilmiştir (Selanikî 1999, 494-495, 509).

III. Mehmed'in bizzat çıktığı Eğri seferinde, Hasan Paşa da maiyetinde bulunan bütün Rumili beyleri, timar ve zeamet sahipleriyle birlikte düzenli bir şekilde Segedin'de orduya katılmıştır (Peçevî 1866, cilt II, 191; Hasan Bey-zade 2004, cilt III, 498). Ordu Eğri üzerine giderken yeniçeri ağası Veli Ağa'ya Rumili beylerbeyliği verilmiştir. Ancak Eğri kuşatmasında Veli Paşa kolunun düşman karşısında başarısız olması nedeniyle Rumili eyaleti tekrar Hasan Paşa'ya tevcih edilmiştir (Selanikî 1999, 636, 641; Hasan Bey-zade 2004, cilt III, 511; Katip Çelebi 2016, 114). Eğri'nin fethedilmesinin ardından Hasan Paşa'ya vezaret hasları tahsis edilmiştir (Peçevî 1866, cilt II, 195; Selanikî 1999, 636). Eğri seferinin dönüşünde Hasan Paşa'nın Belgrad muhafazasında bırakıldığını görmekteyiz (Selanikî 1999, 662; Hasan Bey-zade ise Hasan Paşa'nın sadrazam İbrahim Paşa'nın azledilmesi olayında Cıgalazade'nin yanında olmasından dolayı, kısa süre sonra tekrar sadrazam olan İbrahim Paşa'nın kinine hedef olduğunu ve azledilerek yerine Satırcı Mehmed Paşa'nın serdar olduğunu belirtmiştir. Hasan Bey-zade 2004, cilt III, 546). Hasan Paşa 1597 yılı sonlarında doğru serdar Satırcı Mehmed Paşa'nın Belgrad'a gelmesiyle birlikte İstanbul'a gönderilmiştir. Başkentte Hasan Paşa'nın düşmanları şehre gelmemesi ve Malkara'da ikamet etmesi yolunda haberler gönderse de hayli üzgün olan Paşa İstanbul'a gelmiştir (Selanikî 1999, 707). Hasan Paşa'nın İstanbul'daki üzüntüsü yaklaşık bir ay sonra sevince dönüşmüştür. Zira bu günlerde kendisine vezaret tevcih edilmiştir (Selanikî 1999, 709).

Doğudaki seferlerde alınan sonuçlardan memnun olmayan III. Mehmed, 1598 yılı başında Hasan Paşa'ya ferman göndererek serdarlıkla Bağdad'a gitmesini emretmiştir. Ancak Hasan Paşa gitmek istemeyip, sadrazamlık verilirse serdarlık yapmanın daha kolay olacağı yolunda haber göndermiştir. Aldığı bu cevap üzerine III. Mehmed kapıcılar kethüdasını göndererek padişahın emrine uymasını, aksi halde Yedikule'de hapsedileceğini bildirmiştir. Hasan Paşa bunun üzerine fermana boyun eğerek Bağdad'a gitmek üzere hazırlıklara başlamıştır (Selanikî 1999, 722-723).

Peçevî, Hasan Paşa'nın çelebiliğini övmekte, aynı zamanda düşman karşısında zorlu ve dirençli bir asker olduğunu da belirtmektedir. Ancak İstolni Belgrad ve Hatvan savaşlarında Budin, Peşte gibi uçboyu kalelerindeki emektarların şehit olmasından ötürü buraların zayıf düştügünü ve düşmana firsat doğduğunu söylemektedir. Yine de bütün bunlar Hasan Paşa'nın kahramanlığına gölge düşürememiştir (Peçevî 1866, cilt II, 30).

1599'da Sivas eyaletinin sancaklarından birinde sancakbeyinin kaymakamı olan Karayazıcı isimli biri bulunmaktayd. Bu sancak bir süre sonra başka bir sancakbeyine verilmiş ve o da kendi kaymakamını göndermiş̧tir. Ancak Karayazıcı bu durumu kabul etmeyerek sancağı teslim etmemiştir. Yeni sancakbeyi geldiğinde onu da öldüren Karayazıcı, kaynaklarda Celalî olarak adlandırılan civardaki bütün eşkıyayı kendisine bağlayarak isyana başlamıştır. Asiler üzerine serdarlığa getirilen Sinanpaşazade Mehmed Paşa, başarısızlığ ve hakkındaki şikâyetler nedeniyle azledilerek yerine Hacı İbrahim Paşa getirilmiştir. Ancak Hacı İbrahim'in de Karayazıcı'ya mağlup olması üzerine serdarlık Bağdad valisi Sokolluzade Hasan Paşa'ya tevcih edilerek emrine Diyarbakır, Şam ve Halep askerleri verilmiştir (Katip Çelebi 2016, 194). Hasan Paşa, Karayazıcı'yı bozguna uğratmış ve Canik tarafına kaçan asi şefi bir süre sonra ölmüştür. Ancak Karayazıcı'nın ölümü isyanı sona erdirmemiştir. Asiler onun yerine kardeşi Deli Hasan'1 başlarına geçirmiştir. O sırada Tokat kalesinde bulunan Sokolluzade Hasan Paşa harekete geçerek asilerin üzerine yürümüştür. Asilere mağlup olan serdar Tokat kalesine sığınmıştır. Peçevî’nin "kibirli" olarak tanımladığı Hasan Paşa kibrinin bedelini canıyla ödemek zorunda kalmıştır. Kaleden kaçan bir adam, asilere Hasan Paşa'nın her sabah tek başına kale kapısının yanındaki 
tahta perdeli odaya gittiğini haber vermiş ve burada bekleyen asiler Hasan Paşa'yı başından vurarak şehit etmişlerdir (1600/1) (Hasan Bey-zade, Hasan Paşa'nın Tokat kalesinde yüksek bir kasrda dinlenirken Deli Hasan'ın adamlarından biri tarafından kafasından vurularak şehit düştüğünü kaydetmiştir. Peçevî 1866, cilt II, 31, 252-254; Hasan Bey-zade 2004, cilt III, 696689; Katip Çelebi 2016, 231-232).

Peçevî’nin aktardığı bilgilere göre Hasan Paşa Bağdad valisi iken padişah gibi gösterişli bir şekilde cumaya çıkarmış. Bu durum babası Mehmed Paşa'ya aktarıldığında, Sultan Selim'in gazabından korkan sadrazam, oğlu için "hakkında şikâyet vardır, azl edilsin" yollu arzda bulunmuştur. Hasan Paşa'nın durumunu daha önce haber almış olan Sultan Selim ise azledilmemesini, ancak davranışlarına dikkat etmesi için uyarılmasını emretmiştir (Peçevî 1866, cilt II, 29; Ahmed Refik 2017, 145).

Peçevî İbrahim Efendi, son derece yakışıklı ve yiğit olan Hasan Paşa'nın aynı zamanda mağrur ve kibirli olduğunu da belirtmektedir. Sadece kendine eşit rütbede olanlara değil, üst rütbedekilere de iltifat etmezdi. Hoşuna giden bir genç olursa, onu hazinedarı yapıp, kendi giydiği kıyafetleri ona giydirir, kendininkine benzer bir ata bindirir, benzer kıyafetler giyerek alay selamında yan yana giderlerdi. Sefer sırasında da kendi otağının yanına aynı ihtişamda bir otak daha kurdurur ve kendisini ziyaret için gelenleri, öncelikle hazinedarı ziyaret ettikten sonra huzuruna kabul ederdi. Bağdad beylerbeyi iken kırk-elli bin kuruşluk gümüş bir taht yaptırmış ve üzerini türlü meyvelerle süsleterek adını "cennet köşkü" koymuştur. Hasan Paşa, Celalîler tarafından Tokat kalesinde kuşatıldığı zaman, Bağdad'dan gelen hazinesi Deli Hasan isimli Celalînin eline geçmiş ve cennet köşkü isimli tahtı kurdurarak, kendi adamlarına ibret olsun diye seyrettirmiştir (Peçevî 1866, cilt II, 29-30).

\section{Sokolluzade Mehmed Paşazade Kurd Bey}

Kurd Bey hakkında kroniklerde detaylı bilgi bulunmamaktadır. Sigetvar seferine babası ve kardeşi Hasan Bey'le (daha sonra Paşa) birlikte katılmıştır. Selanikî, Sigetvar seferinde Peçuy sahrasına gelindiğinde padişahın vezirlerden alaylarını göstermesini istediğini ve sadrazam Sokollu Mehmed Paşa'nın oğulları Kurd Bey ve Hasan Bey ile o dönemde ulufecibaşı olan Ferhad Ağa'nın da alaylar halinde padişahın önünden geçtiklerini belirtmiştir. Yine Selanikî, Sokoloviç ailesinin bu üç ferdinin de sadrazamın "evlâd-ı kiramından" olduğunu kaydetmiştir (Selanikî 1999, 27). Ahmed Refik ise Kurd Bey'in Hüsrev Paşa'nın oğlu olduğunu iddia etmektedir (Ahmed Refik 2017, 89). Kurd Bey hakkında kroniklerdeki bilgiler bununla sınırlı olmakla birlikte ölümünden sonra babasının oğlu adına kurduğu vakfın vakfiyesinde ismi Kasım olarak geçmektedir. Kurd Bey'in ölümüne dair kroniklerde bilgi yoktur. Bununla birlikte Evliya Çelebi'nin Seyahatname'sinde aktardığına göre Kasım Paşa'nın Budin valiliği sırasında halka zulmettiğine dair şikayetlerin İstanbul'a ulaşması üzerine Sultan Selim, Sokollu Mehmed Paşa'yı uyararak oğlunun zulmüne son vermesini istemiştir. Bu uyarıdan sonra Mehmed Paşa padişahtan oğlunun idamına dair ferman alıp kapıcısıyla Budin'e göndermiş ve oğlu burada idam edilerek kesik başı İstanbul'a getirilmiştir (Evliya Çelebi 1999, cilt III, 251-252). Mühimme kayıtlarına göre 1571 yilında hayatta bulunan Kurd Bey, Nisan 1574 tarihli vakfiyede merhum olarak anılmıştır. Bu bilgilere göre Kurd Bey, bu iki yıl arasındaki bir tarihte idam edilmiştir (Mehmed Paşa'nın idam ettirdiği oğlu Kurd (Kasım) Bey'in hayatı ve babasının adına kurduğu vakıfla ilgili detaylı bilgi için bkz. Yıldız 2014, 97-114).

\section{Sokollu Mehmed Paşazade İbrahim Han}

Sokollu Mehmed Paşa'nın İsmihan Sultan'dan olan ve 1565 yılında doğduğu tahmin edilen İbrahim Han, bir süre gizlendikten sonra II. Selim saltanatında ortaya çıkarılmış ve dedesi Sultan 
Selim tarafından kendisine "Han" unvanını kullanma izni verilmiştir. Bu nedenle İbrahim Han'ın soyundan gelenler İbrahim Hanzadeler olarak anılmıştır. İbrahim Han'ın soyundan gelenler, 1703 'te Sultan II. Mustafa'nın tahttan indirilmesinin ardından Osmanlı hanedanına bir alternatif olarak gündeme gelmiştir (Detaylı bilgi için bkz. Emecen 2002, 1877-1886).

Selanikî, 1594 yılı sonlarında İbrahim Bey’in kapıcıbaşılık görevine talip olduğunu kaydetmiştir (Selanikî 1999, 390). Kapıcıbaşılık görevine atanan İbrahim Ağa için "sultanzade" unvanını kullanan Selanikî, 1596 baharında İbrahim Ağa'nın Eğri seferine iştirak etmek için kapı halkını hazırlamışken padişahın gazabına uğradığını ve kapıcıbaşılıktan azledildiğini kaydetmiştir (Selanikî 1999, 608). Ancak İbrahim Ağa kısa bir süre sonra tekrar kapıcıbaşılığa, ayrıca Matbah1 Amire'nin ihtiyaçlarını gidermesi için şehreminliğine getirilmiştir (Gökbilgin 1979c, cilt V/2, 894; Emecen 2000, 316). Selanikî, 1597 yaz aylarında İbrahim Ağa'nın bütün beylerbeyleri ve diğer ümeranın Erdel seferine çıkan Satırcı Mehmed Paşa'ya katılması için sadrazam tarafından ahkâm ile gönderildiğini kaydetmiştir (Selanikî 1999, 696).

1602 yılında, Celalî reisi Deli Hasan isyanını bastırmak üzere Tokat’ta bulunan Sokolluzade Hasan Paşa, bu görevden azledileceğine dair haber alınca İstanbul'a adam göndererek azil haberini getiren kapıcıbaşıyı katledeceğini belirtmiştir. Bu tehdide rağmen Hasan Paşa'nın azil haberi, kardeşi kapıcıbaşı İbrahim Ağa (Han) ile gönderilmiştir. Tokat'a gelen İbrahim Ağa, Hasan Paşa tarafından kovulmuş, bir süre sonra Hasan Paşa'nın şehit düşmesiyle bu olay büyümeden kapanmıştır (Naîmâ Mustafa Efendi 2007, cilt I, 208). I. Ahmed'in tahta geçmesinin ardından, 1604 yılında zaim olan oğlu Abdullah'la birlikte seferlere katılmama ve padişah sefere çıktığı vakit sefere katılma gibi bazı imtiyazlarla birlikte başkapıcıbaşı olarak tayin edilen İbrahim Ağa, kısa bir süre görevden alınmışsa da tekrar bu görevine iade edilmiştir (Emecen 2000, 316).

Fatih kanunnamesinde kız çocukların evlatlarının beylerbeyliğe getirilmemesi şeklindeki hükme rağmen (Özcan 2017, 22), babasından kalan Atmeydanı'ndaki sarayın arsasını Sultan Ahmed Camii inşaatı için bağışlamasının da etkisiyle 1610 yılında Bosna beylerbeyi olarak tayin edilmiştir (Emecen 2000, 316). Bu görevinde 1615 yılına dek kaldığı anlaşılan İbrahim Paşa, bu görevin ardından bir süre Rumili beylerbeyliği yapmış, 1618 yılında da Hersek mutasarrıflığına getirilmiştir. Ertesi sene tekrar Bosna'ya tayin edilen İbrahim Paşa, 1622 yılında bu görevinden ayrılarak İstanbul'a gelmiştir. Aynı yıl burada vefat eden İbrahim Paşa, babasının Eyüp'teki türbesine defnedilmiştir (Gökbilgin 1979c, cilt V/2, 895). Nesli, oğlu Mehmed Bey’den (Defter eminliği yapan Mehmed Bey, H. 1077'de (Temmuz 1666) veba nedeniyle vefat etmiştir. Mehmed Süreyya 1996, cilt III, 964) ve sırasıyla Ali (1695-96 yılında (H.1107) savaşa katılması istenen Ali Bey, 1715 yılında 63 yaşındayken hummadan vefat etmiştir. Mehmed Süreyya 1996, cilt I, 247), Bahir İsmail (Şair ve hattat olan Bahir İsmail Bey, 1751 y1lında vefat etmiştir. Mehmed Süreyya 1996, cilt II, 353) ve Ahmed Beyler üzerinden devam etmiş̧tir (Mehmed Süreyya 1996, cilt III, 782).

\section{Lala Mehmed Pașa}

Sokollu Mehmed Paşa'nın amcazadesidir. Bir kaynağa göre Budin beylerbeyi Mustafa Paşa'nın kardeşidir (Muvakkit Salih Sıdkı Efendi ?, cilt I, 221). Lala unvanına, sarayda görev yaparken şehzadelerin eğitiminde görev aldığı için sahip olduğu tahmin edilmektedir (Ak 2003, 71). Saraydan taşra çıktıktan sonra mirahurluk yapmış, 1591 yılı başlarında ise Saatçi Hasan Paşa'nın yerine yeniçeri ağalığına getirilmiştir (Katip Çelebi 2016, 377). 1594 yılında Yanıkkale üzerine giden serdarın emrindeki orduya, yeniçeri ağası olarak on sekiz bin yeniçeri ile iştirak etmiştir. $\mathrm{O}$ döneme dek yeniçeri ağalarının serdarlarla birlikte sefere gitmesi zorunlu olmadığı halde, cesareti ve hırsının yanı sıra, Sinan Paşa'nın sahte vaatlerinden ötürü sefere katılmıştır (Hasan Bey-zade 
2004, cilt II, 390). Ancak Tata kalesinin aman ile elde edilmesinin ardından Sinan Paşa'nın kininden ötürü ağalıktan azledilmiş ve yerine Sinan Paşa gibi Arnavut olan Yemişçi Hasan Ağa getirilmiştir (Peçevî 1866, cilt II, 145). Selanikî, bu azilden sonra Mehmed Ağa'nın Karaman beylerbeyliğine getirildiğini kaydetmiştir (Selanikî 1999, 384). Peçevî’nin kaydına göre kısa süre sonra Mehmed Paşa'nın Anadolu beylerbeyliğine getirildiği anlaşılmaktadır. Zira seferin devam ettiği yıl serdar, orduyla birlikte Eflak üzerine gönderilince, Budin ve İstolni Belgrad tarafinın korunmas1, o sırada Anadolu beylerbeyi olan Lala Mehmed Paşa'ya havale edilmiştir. Mehmed Paşa önce İstolni Belgrad'a gitmiş, ardından buradan hareketle Budin'e varmıştır (Peçevî 1866, cilt II, 165; Selanikî 1999, 662; Katip Çelebi 2016, 58, 69). Burada vezir-i azam Sinan Paşa'nın oğlu Mehmed Paşa Budin civarının muhafazası ile görevlendirilmiş idi. Cephede bulunan bütün beylerbeyleri ve bunların askerleri Budin'e gelerek ordugâha katılmıştır. Bir süre sonra Avusturyalıların Estergon'u kuşattı̆g 1 haberi gelmiş ve ordu buraya hareket etmiştir. Ancak düşman askerinin baskını karşısında korkan serdar, Budin'e firar etmiştir. Bu sırada Sokollu Mehmed Paşa'nın akrabasından olan Kara Ali Bey, paşanın yanına gelerek serdarın gittiğini haber vermiş ve kendisinin de gitmesini istemiştir. Ancak Mehmed Paşa'nın başında olduğu Anadolu kolu Estergon kalesine girmeyi başarmıştır. Burada Kara Ali Bey, Mehmed Paşa'nın kaleden gizlice çıkmasını, geri kalan askerin de kaleyi vire ile teslim etmesini teklif etmiştir. Ancak Mehmed Paşa bu teklifi reddetmiştir (Katip Çelebi 2016, 79).

Kuşatmanın ilerlediği günlerde askerin mücadele edecek gücü kalmamış ve Mehmed Paşa’ya giderek kaleyi vire ile teslim etmesini talep etmişlerdir. Ancak Mehmed Paşa ölene dek direnerek kaleyi teslim etmeyeceğini bildirmiştir. Bu cevap üzerine asker önce Mehmed Paşa'ya saldırmış, ardından Estergon beyi Seyit Bey'i yakalayarak yaralamıştır. Ertesi gün vire şartlarını görüşmek üzere giden Peçevî İbrahim Efendi, Avusturyalılar ile kale halkının malını beraberinde götürmesi karşılığında anlaşmıştır. Kaleye dönen Peçevî, Mehmed Paşa'nın ağladığını görerek kederlenmiş ve Estergon'un geri alınmasında da vire şartlarını kendisinin görüşmesini niyaz etmiştir. Birkaç günlük hazırlıktan sonra Osmanlı kuvvetleri Estergon'u terk ederek Budin'e hareket etmiştir (Peçevî 1866, cilt II, 181-187; Katip Çelebi 2016, 88-89).

Sultan III. Mehmed, sadrazam Sinan Paşa'nın ve Hoca Sadeddin'in telkinleriyle bizzat Eğri seferine gitmeye karar vermiştir (Katip Çelebi 2016, 93). Padişahın Eğri kalesini kuşatmasının ertesi günü, Budin muhafazasında olan Anadolu beylerbeyi Mehmed Paşa da Eğri’ye gelmiştir (Katip Çelebi 2016, 108). Eğri Kalesi yaklaşık yirmi günlük bir kuşatmanın ardından fethedilmiştir. Eğri'nin fethinden sonra kalenin muhafazasına da eyaleti askeriyle birlikte Anadolu beylerbeyi Mehmed Paşa bırakılmıştır. Ancak daha sonra gönderilen buyuruldu ile Mehmed Paşa'nın da padişahın maiyetine katılması emredilmiştir (Hasan Bey-zade 2004, cilt III, 514-516; Katip Çelebi 2016, 115-116). Padişah komutasındaki Osmanlı ordusu buradan Haçova'ya hareket etmiştir. Lala Mehmed Paşa, Haçova savaşına Rumeli ordusunun başı olarak sağ tarafta katılmıştır. Burada kazanılan zaferin ardından padişah İstanbul'a dönmüştür (Tekindağ 1979, 592; Katip Çelebi 2016, 127).

1598 yılında Rumili beylerbeyi Veli Paşa'nın vefat etmesi üzerine bu görev Anadolu beylerbeyi Mehmed Paşa'ya tevcih edilmiştir (Selanikî 1999, 765; Hasan Bey-zade 2004, cilt III, 575; Katip Çelebi 2016, 146). Tayin hükmü o sırada Ösek tarafında bulunan Mehmed Paşa'ya geldiğinde Paşa derhal harekete geçerek Beçkerek'e gelmiş ve serdarın emrine katılmıştır. Daha sonra Kırım askerinin de katıldığı ordu Çanad'ı fethetmiştir. Varat kuşatması devam ederken Avusturya askerinin Budin'i kuşattığı haberi gelmiş ve kuşatma kaldırılarak Budin'e hareket edilmiştir. Ancak dönüş yolunda askerler arasındaki huzursuzluk nedeniyle yolda karar değiştirilmiş ve ordu Segedin'e yönelmiştir. Serdar Satırcı Mehmed Paşa Kırım askerini Segedin, 
Peçevî'nin de dâhil olduğu Mehmed Paşa emrindeki askeri ise Peçuy tarafina kışlamaya göndermiş ve Varat seferi bu şekilde nihayet bulmuştur (Peçevî 1866, cilt II, 214-223).

Ertesi y1l Mehmed Paşa'ya Budin seraskerliği de verilmiştir (Selanikî 1999, 838). Rumili beylerbeyinin askerin yanında olması gerektiğini düşünen Paşa, Budin'i Tiryaki Hasan Paşa'ya vererek beş büyük topla Kanije'ye gelmesi emrini göndermiştir. Kanije kuşatması sırasında kaledeki barut mahzenine ateş düşmesi sonucu çok sayıda Macar ölmüş ve kale kolay bir şekilde ele geçirilmiştir (Peçevî 1866, cilt II, 232-233; Hasan Bey-zade Kanije'nin kuşatma sonunda vire ile alındığını kaydederken barut mahzenine ateş düşmesi olayından bahsetmemiştir. Hasan Beyzade 2004, cilt III, 636).

1601 y1lında serdar İbrahim Paşa ölmüş ve yerine Yemişçi Hasan Paşa serdar atanmıştır. Kısa süre sonra Avusturya askerinin İstolni Belgrad'1 kuşattığ haberi gelmiştir. Serdar derhal buraya yönelmişse de kale yoğun saldırılara dayanamamış ve düşmüştür (Peçevî 1866, cilt II, 236 vd; Hasan Bey-zade, Yemişçi Hasan Paşa'nın serdarlık emrini aldığı zaman İstanbul'dan hareket edildiğinde geç kalınacağı ve Mehmed Paşa'nın sınır muhafazasında bırakılarak kendisinin hazırlıklarını tamamladıktan sonra nevruzda sefere gitmesinin daha doğru olacağı yönünde bir arz sunduğunu, ancak şeyhülislam Sunullah Efendi'nin etkisiyle padişahın bunu kabul etmediğini kaydetmiştir. Müellife göre Lala Mehmed Paşa o yıl serdar olarak muhafazada bırakılmış olsaydı ordu iki ay önce sınırı kontrol altına alacak ve İstolni Belgrad kaybedilmeyecek, ayrıca Estergon'un bile ele geçirilecekti. Hasan Bey-zade 2004, cilt III, 658-659). Kale kuşatması devam ederken Mehmed Paşa, kişisel hırsları nedeniyle zor durumda olan Budin beylerbeyi Mehmed Paşa ve eski serdar İbrahim Paşa'nın kethüdası Mehmed Kethüda'ya yardım etmemiş ve düşman arasında kalan bu iki komutan şehit düşmüştür (Hasan Bey-zade 2004, cilt III, 663). Aynı yıl Mehmed Paşa Budin muhafızlığına gönderilmiştir. 1602 kışını Belgrad kışlağında geçiren serdar Hasan Paşa, 1603 baharında İstolni Belgrad'ı kuşatmış, Budin muhafızı Mehmed Paşa da buraya gelerek kaleyi güney tarafından kuşatmıştır. Kale toplarla dövülürken Mehmed Paşa'nın kullarından birisi omzunda bayrakla kuleye çıkmış ve onu takip eden yeniçeriler kısa sürede kuleyi ele geçirmiştir. Mehmed Paşa da askerlerle beraber kaleye girmiş ve kısa süre sonra Macarların aman dilemesi üzerine kale ele geçirilmiştir. Burada kalenin ihtiyaçları tamamlandıktan sonra ordu Budin'e dönmüştür (Peçevî 1866, cilt II, 242-243).

Yemişçi Hasan Paşa Belgrad'da kışladığı sırada Erdel bölgesinde yaşayan Sekellerin önde gelenlerinden bir bey yardım istemek için huzuruna gelmiştir. Hasan Paşa bu beyin teklifini olumlu karşılamış, ancak İstolni Belgrad'ı ele geçirmeden Erdel'e sefer düzenlemek faydasız olacağı için bu konu ertelenmiştir. İstolni Belgrad ele geçirildikten sonra serdar Hasan Paşa Erdel'e gitmek üzere Belgrad'dan harekete geçmiştir. Budin'de hazırlıklar tamamlandıktan sonra Erdel'e doğru yola çıkılmıştır. Ancak düşman askerinin Estergon'un karşısındaki Ciğerdelen'de beklediği yolundaki istihbarata rağmen Yemişçi Hasan Paşa uyarıları dikkate almamış ve hareketine devam etmiştir. Osmanlı ordusunun uzaklaştı̆̆ını gören Avusturyalılar ise Budin'i bir kez daha kuşatmıştır. Osmanlı kuvvetleri derhal geri dönerek Peşte'de bulunan düşman kuvvetlerini toplarla dövmeye başlamıştır. Osmanlı askeri, Budin kuşatma altındayken Mehmed Paşa'nın daha önce yaptırmış olduğu geçitten Budin kalesine girmiştir. Ancak Budin'de zahirenin tükenme tehlikesi ortaya çıkınca ordunun ileri gelenleri Yemişçi Hasan Paşa'ya giderek Mehmed Paşa'yı bir miktar asker ile Budin kalesinde bırakarak kalan askerin ayrılmasını teklif etmiştir. Ancak iki yıldır Budin muhafazasında görev yapan Mehmed Paşa bu teklife sıcak bakmamış, askerin ısrarı sonucu kabul etmek zorunda kalmıştır. Peçevî, Mehmed Paşa'nın bu isteksizliğinin daha önce Yemişçi Hasan Paşa ile arasındaki anlaşmazlıktan kaynaklandığını belirtmiştir. Mehmed Paşa'nın emrindeki askerler Avusturya askerine hücuma geçmiş ve kısa süre sonra 
Budin kurtarılmıştır (Peçevî 1866, cilt II, 243-250).

Bundan sonra Yemişçi Hasan Paşa serdarlığı Mehmed Paşa'ya bırakarak İstanbul'a dönmüştür. O sırada Bosna beylerbeyliği verilerek itaat altına alınan Celalî reisi Deli Hasan da maiyetiyle birlikte Mehmed Paşa'nın emrine gelmiştir. Avusturya kuvvetleri Peşte'nin güneyindeki Çepel adasına köprü kurarak yerleşmişlerdi. Osmanlı gemilerinin Tuna yolunu kullanmasına engel olan Avusturya askerinin buradan çıkarılması için girişilen harekâtta çok sayıda Celalî eşkıyası ölmüştür. Deli Hasan bu seferden dönüşünde Bosna'da âdeti üzere uygunsuz davranışlarına devam etmiştir. Sınır boyunda Sefer Bey isimli bir bey etrafına topladığı adamlarla Deli Hasan'a karşı harekete geçmiştir. İlk çarpışmada mağlup olan Sefer Bey, tekrar adam toplayarak hücum etmiş ve Deli Hasan'ı bozguna uğratmıştır. İzvornik tarafına kaçan Deli Hasan'a adam gönderen Mehmed Paşa, onu Tımışvar valiliğine ikna ederek bu olayı sona erdirmiştir (Peçevî 1866, cilt II, 272-276; Hasan Bey-zade 2004, cilt III, 760; Katip Çelebi 2016, 296).

1603 yılında III. Mehmed'in ölümü ile Osmanlı tahtına I. Ahmed geçmiştir. Sultan, Mehmed Paşa'yı yine Macar serdarlığında bırakmak istemiştir. İstanbul'daki devlet ricali arasındaki görüşmede de sadrazamın merkezde bulunması ve hem doğu hem de batıdaki cephelere serdar tayin edilmesi kararlaştırılmıştır. Ancak daha sonra Sultan Ahmed kararını değiştirerek sadrazamın bizzat sefere gitmesine dair emir vermiştir. Sadrazam Ali Paşa'nın Belgrad'a geldikten birkaç gün sonra ölmesi üzerine sadaret mührü Sokollu ailesinden Mehmed Paşa'ya verilmiştir (Abdülkadir Efendi 2003, 418; Hasan Bey-zade 2004, cilt III, 828). Sadaret mührünü alan Mehmed Paşa vakit kaybetmeden 1604 yılının Ekim ayında Estergon kalesini kuşatmıştır. Yaklaşık bir ay süren kuşatma sonuca ulaşmamış, askeri Budin'e götüren Mehmed Paşa daha sonra sınırların durumunu bildirmek amacıyla İstanbul'a dönmüştür (Katip Çelebi 2016, 324325). Ertesi yıl sefer mevsiminde tekrar Macaristan üzerine serdar olarak atanan Mehmed Paşa 1605 yılı Mayıs ayında İstanbul'dan hareketle Belgrad üzerinden Budin'e doğru yola çıkmıştır. Budin yakınlarında toplanan divanda askerlerin çoğu Estergon'un ele geçirilmesinin zor olduğunu, bu nedenle Viyana tarafına akında bulunmanın daha faydalı olacağını belirtmiştir. Ancak yolda yeniçerilerin ağırlıklardan şikâyet etmesi üzerine sadrazam Mehmed Paşa fikrini değiştirerek Estergon'un kuşatılmasına karar vermiştir. Estergon kalesi Ağustos sonlarında kuşatılmıştır. Kuşatma devam ederken civarda bulunan Vişegrad ve Depedelen ele geçirilmiştir. Bir süre sonra kalenin varoşunun da fethedilmesi üzerine kale halkı kaleyi vire ile teslim etmeyi teklif etmiş ve Estergon Kalesi Ekim 1605'te tekrar Osmanlı kontrolüne girmiştir (Katip Çelebi 2016, 337-342). Mehmed Paşa kalenin teslim alınmasından sonra durumu Peçevî İbrahim Efendi vasitasıyla İstanbul'a iletmiştir. Peçevî bu dönemde piyade mukabeleciliğinde bulunurken, müjde haberiyle birlikte süvari mukabeleciliğine yükselmiştir (Peçevî 1866, cilt II, 290-307).

Macar serhaddinde büyük hizmetleri geçen Mehmed Paşa, Estergon'un elde edilmesinin ardından İstanbul'a dönmek istemiş ve isteği kabul edilmiştir (Hasan Bey-zade'nin kaydına göre Sultan Ahmed, hocasının etkisiyle İran seferine sadrazamın serdar olması için o sırada Belgrad'da olan Mehmed Paşa'ya hatt-1 hümayun göndererek İstanbul'a gelerek baharda İran seferine gitmesini, bunu kabul etmezse padişahın mührünü göndererek ikinci vezirlik ile Macar serdarlığında kalmasını emretmiştir. Bunun üzerine derhal İstanbul'a gelen Mehmed Paşa, hazırlıklara başlamış ancak yerine Kürt aşiretlerine yakınlığı bulunması dolayısıyla Nasuh Paşa'nın tayin edilmesi için çalışmış, bunda başarılı olamayınca sefere çıkmak üzereyken vefat etmiştir. Hasan Bey-zade 2004, cilt III, 872-873). Ancak kaptan-1 derya Derviş Paşa'nın etkisinde olan Sultan Ahmed, Mehmed Paşa'yı İran serdarlığına tayin etmiştir (Hasan Bey-zade 2004, cilt III, 839; Katip Çelebi ise Anadolu'da Celalî olaylarının çoğaldığını, devlet ricalinin bu olayların bastırılması için sadrazamın serdar olarak gitmesi gerektiği konusunda fikir birliğine vardıkları için 
Mehmed Paşa'nın İstanbul'a davet edildiğini kaydetmiş, ancak eserin devamında Sultan Ahmed'in Mehmed Paşa'yı İran serdarlığına tayin ettiğini belirtmiştir. Katip Çelebi 2016, 355, 360). Macar serhaddinin dördüncü vezir Murad Paşa'ya havale edilmesinin ardından Mehmed Paşa İstanbul'a dönmüştür. Mehmed Paşa'nın Macaristan'daki işlere devam edilmesi durumunda Avusturya ile barışın sağlanabileceği ve tekrar haraca bağlanacağı yolundaki itirazı sonuç vermemiştir. Mehmed Paşa'nın Peçevî İbrahim Efendi'ye anlattığına göre sadrazam Erdel kralı yaptığ1 Boçkayi ile birlikte harekâta devam etmeyi ve Viyana'ya kadar ilerlemeyi tasarlamıştır (Peçevî 1866, cilt II, 316-318; Katip Çelebi 2016, 360).

Mehmed Paşa'nın sefer hazırlıkları devam ederken Celalî reislerinden Kalenderoğlu, daha önce hizmetinde çalıştığ 1 sadrazama mektup göndererek sancakbeyliği verilmesi karşıllğında bütün Celalî eşkıyasını emrine toplayacağını, sancak hemen verilmese bile itaat edeceğini bildirmiştir. Diğer Celalî reislerinden Tavil de itaatini bildirmiş, Canbolatoğlu ise itaatini bildirirken Haleb valiliğinin üzerinde bırakılmasını talep etmiştir. Ancak yine Derviş Paşa Celalîlerin bu itaatini inandırıcı bulmamış, ayrıca Mehmed Paşa'nın yakın adamlarına da birer sancakbeyliği vererek ondan uzaklaşmasını sağlamıştır. Ayrıca kendisi de Sokoloviç ailesinden olan Derviş Paşa'nın padişaha kendisi hakkında söylediği kötü sözleri de haber almıştır (Muvakkit Salih Sıdkı Efendi ?, cilt I, 223). Bütün bu yaşananlar Mehmed Paşa'yı üzüntüye sevk etmiş ve hazırlıklarını tamamlayan sadrazam İstanbul'dan ayrılmasına üç gün kala felç geçirmiştir. Sadrazamın bu durumuna karşın Derviş Paşa'nın zulmü bitmemiştir. Padişahı sadrazamın hastalığının yalan olduğuna ikna eden Derviş Paşa, sadrazamın "gerekirse taht-1 revan ile revane olup" derhal sefere hareket etmesini emreden bir hatt-1 şerif yollatmıştır. Mehmed Paşa padişaha bir tezkire ile durumunun kötü olduğunu ve bir adam göndererek kontrol ettirmesini talep etmiştir. Gönderilen kap1 ağası sadrazamın durumunu görmüş ve hareket etmeye imkânı olmadığını padişaha arz etmiştir (Hasan Bey-zade 2004, cilt III, 841-844; Katip Çelebi 2016, 361-362). Hekimlerin tedavi çabaları ile iki gün hasta yatan Mehmed Paşa, 22 Haziran 1606'da vefat etmiş ve Eyüp'teki türbesine defnedilmiştir. Ölümünden sonra Kisbî tarafından şu şekilde tarih düşürülmüştür:

\section{'Acem 'e gitmeğe me'mûr idi, dedi Kisbî târîhini \\ 'Ademe gitdi meded hay Mehemmed Paşa (Katip Çelebi 2016, 377)}

Peçevî, Mehmed Paşa'nın hasta olduktan sonra tedavisiyle ilgilenen Portekizli hekim tarafindan zehirlendiğini belirtmektedir. Sadrazamın fenalaştığı sırada oraya gelen doktor, zehirleme iddialarını reddederek Paşa'nın istirahat tavsiyesini dinlemediğini, haremde çok vakit geçirdiğini söyleyerek kendisini savunmuştur (Peçevî 1866, cilt II, 320-321).

Peçevî İbrahim Efendi, sadrazamın akrabası olup on beş yıl hizmetinde kalmıştır. Bu yakınlığı dolayısıyla Paşa'ya dair ilk elden gözlemlerini aktaran Peçevî'ye göre Mehmed Paşa mütevazı, kibirden arınmış, yalandan ve böbürlenmeden uzak, iyi huylu bir kimsedir. Askeri vasıfları ise düşman karşısında sabırlı ve yiğit olmasıdır. Peçevî, Paşa'nın en göze batan özelliğinin cimrilik olarak söylendiğini, ancak Estergon'un fethinin ardından timar ve zeametler dışında Paşa'nın askerlere cebinden de para verdiği belirterek, bu konuda Mehmed Paşa'ya haksızlık yapıldığını kaydetmiştir. Mehmed Paşa öldükten sonra yüz elli bin altın ve yüz yük guruştan oluşan nakit parasının yanında sayısız kürk ve gümüş eşyası tespit edilmiştir. Ancak padişahın Mehmed Paşa'nın çocuklarına bıraktığı bu mirasa Derviş Paşa tarafından el konulmuştur (Peçevî 1866, cilt II, 321-322).

\section{Kara Ali Bey}

Lala Mehmed Paşa'nın akrabası olan ve hakkında çok fazla bilgi bulunmayan Kara Ali Bey (Samarcic, Kara Ali Bey’in, Sokollu Ferhad Paşa'nın kardeşi olduğunu kaydetmiştir. Samarcic 
1995, 262), İstolni Belgrad ve Estergon'da on beş yıla yakın valilik yapmıştır. Peçevi'nin aktardığına göre oldukça cesur bir asker olan Ali Bey, Peçuy kalesini savunmakla görevli mirliva rütbesinde bir askerken serdar Mehmed Paşa'dan izin alarak evine ailesini ziyaret etmeye gitmiştir. Bu sırada Avusturyalıların Budin'i kuşatması üzerine derhal hareket etmiş ve buradan da Estergon'u kuşatmış olan düşman üzerine varmıştır. Burada pek çok düşman askerini öldüren Ali Bey, kaleye girmeye muvaffak olmuştur (Selanikî 1999, 502). Peçevî de Kara Ali Bey'in yanındayken Estergon'da kuşatılmışlar, Ali Bey bu esnada bir tüfek mermisi ile vurularak şehit olmuştur (Peçevî 1866, cilt I, 452; cilt II, 177; Katip Çelebi 2016, 79).

\section{Sonuç}

Osmanlı Devleti'nde İstanbul'un fethinden önce sadrazamlığa getirilen devlet adamlarını Türk kökenliler oluştururken, İstanbul'un fethinin ardından bu durum tersine dönmüş ve sadrazamlığa getirilen devlet adamlarının büyük çoğunluğunu devşirme kökenliler oluşturmuştur. Osmanlı Devleti'nde yüksek makamları elde etmeyi başaran devlet adamları, bu makamları elde ettikten sonra kendilerine yakın kişilerden oluşan bir çevre oluşturarak güçlerini muhafaza etmeye çalışmışlar ancak devşirme kökenli idarecilerin ailelerinden kimseleri önemli konumlara getirerek kendilerine tabi yüksek bir sınıf yaratmaları bu dönemde mümkün olmamıştır. Uclarda görev yapan Evrenoszadeler, Turahanzadeler, Mihaloğulları gibi akıncı aileler hariç tutulursa devletin merkezindeki en etkili aile, bünyesinden pek çok kazasker ve sadrazam çıkarmayı başaran Türk kökenli Çandarlı ailesidir. Osmanlı Devleti'nde Çandarlı ailesi dışında dikkat çeken bir başka vezir ailesi de devşirme kökenli olan Köprülülerdir. 1656 yılında sadrazam olan Köprülü Mehmed Paşa'nın ölümünden sonra oğulları Fazıl Ahmed Paşa ve Fazıl Mustafa Paşa, damatları Kara Mustafa Paşa ve Siyavuş Paşa, yeğeni Amcazade Hüseyin Paşa ve torunu Numan Paşa sadrazamlığa getirilmiş ve aile 17. yüzyılın ikinci yarısına adeta damga vurmuştur. Köprülü ailesinin tesiri yirminci yüzyıl başlarına dek sürmüş olup, Türk siyaset ve ilim hayatının önemli isimlerinden Mehmed Fuad Köprülü de bu aileye mensuptur.

Osmanlı Devleti'nde Köprülülere denk sayılabilecek devşirme kökenli bir başka aile de Sokoloviç ailesidir. Bosna'nın Sokolovići köyünün önde gelen ailelerinden olan Sokoloviçlerin Osmanlı Devleti'ne hizmetleri, II. Bayezid döneminde devşirilen ve Divane ya da Deli lakabıyla anılan Hüsrev Paşa ile başlamıştır. I. Selim ve I. Süleyman dönemlerinde hem Anadolu hem de Rumeli yakasında pek çok sefere katılan Hüsrev Paşa, I. Süleyman döneminde sadrazamlığı elde etmeye çok yaklaşmış olsa da Rüstem Paşa'nın tuzağına düşerek vezirlikten de olmuş ve bu olaydan kısa bir süre sonra vefat etmiştir.

Sokoloviç ailesinin şöhreti on dört yıl sadrazamlık yapan Mehmed Paşa ile zirveye ulaşmıştır. Kanuni Sultan Süleyman döneminin başlarında devşirilen ve saraydaki görevlerinde gösterdiği başarıyla sivrilerek taşra çıkan Sokollu Mehmed Paşa kaptan-1 derya, beylerbeyi, vezir gibi rütbeleri elde etmeyi başarmış, Kanuni Sultan Süleyman saltanatının sonlarında sadrazam olarak gücünün zirvesine yükselmiştir. I. Süleyman saltanatının son yıllarında sadrazamlığa getirilen Mehmed Paşa, II. Selim döneminin tamamında ve III. Murad saltanatının ilk beş yılında konumunu muhafaza etmeyi başarmıştır. Saraydaki görevlerini liyakatle yapmasıyla sivrilen Mehmed Paşa, konumunu sağlama aldıktan sonra da akrabalarını himaye etmiştir. Fleischer'ın tabiriyle bir "intisap imparatorluğu" kurmayı amaçlayan Mehmed Paşa'nın himayesinde ailenin çok sayıda üyesi devlet hizmetinde önemli görevlere getirilmiştir. Tarihçi Peçevi, Sokoloviç ailesinden iki sadrazam, beş vezir yetiştiğini belirtmiş, on beylerbeyi çıkaran aileden yetişen komutan ve ayanların sayısının ise bilinmediğini kaydetmiştir. Sokollu ailesinin devlet hizmetindeki bu yayılımı, hizip çatışmalarının yoğun olarak yaşandığ 1 Osmanlı ricali arasında da tepkilere neden olmuş, özellikle III. Murad saltanatında Sokollu Mehmed Paşa'nın rakipleri, akrabalarını 
kayırdığı gerekçesiyle sadrazamın aleyhinde faaliyetlerde bulunmuştur. Sokollu Mehmed Paşa'nın bu politikası, bazı yazarlar tarafından da tenkit edilmiştir. Örneğin Hırzü'l-Müluk müellifi, Sokollu Mehmed Paşa'nın bu politikasını devlet içinde bozulmalara neden olacağ gerekçesiyle eleştirmiştir. Sokoloviç ailesiyle akrabalık bağı bulunan Peçevi ise Sokollu Mehmed Paşa'nın akrabalarını kayırdığı için bazı yazarlar tarafından eleştirildiğini belirtirken, Sokoloviç ailesi mensuplarının kendilerine tevdi edilen görevleri layıkıyla yaptıklarını kaydederek, en azından bu kayırmacılığın devlet için olumsuz bir sonuç doğurmadığını vurgulamaktadır. Nitekim Sokollu Mehmed Paşa'nın 1579'daki ölümünün ardından oğlu Hasan Paşa'nın çeşitli eyaletlerde valilik yapması ve İran sınırındaki hizmetleri ve Lala Mehmed Paşa'nın ise sadrazamlığa dek yükselmiş olması, aile mensuplarının devlet kademelerinde liyakatleri sayesinde yükseldiklerini de kanitlamaktadir.

Sokollu Mehmed Paşa'nın özellikle II. Selim dönemindeki faaliyetleri dikkat çekicidir. II. Selim'in bütün işleri kendisine bırakması nedeniyle adeta "tek adam" gibi hüküm süren Mehmed Paşa, her ne kadar akim kalsa da İtil-Ten nehirlerinin birleştirilerek Kafkasya' daki Rus ilerleyişini durdurmaya ve donanmanın İran üzerine sevk edilmesini mümkün kılmaya çalışmıştır. Sadrazam bulunduğu sırada bu gibi projeler geliştirmenin yanı sıra, kendisine içten içe düşman olan rakipleriyle de uğraşmak zorunda kalmıştır. Rakiplerinin bu çabaları III. Murad üzerinde etkisini göstermiş, Paşa'nın yönetimdeki etkisi gün geçtikçe azalmıştır. Önce yıllarca birlikte çalıştığ 1 nişancı Feridun Bey görevinden uzaklaştırılmış, ardından amcazadesi Mustafa Paşa bir bahaneyle katledilmiştir. Daha sonra bir divane tarafından hançerlenen Mehmed Paşa'nın ölümünün ardında sultan ve maiyetinin mi, yoksa başka bir gücün mü olduğu tarihte bir sır olarak kalmıştır. Avrupalı kaynakların rüşvetçi olarak tavsif ettiği Mehmed Paşa için Osmanlı kronikleri aksini iddia etmektedir.

Sokollu Mehmed Paşa'yla aynı dönemde devşirilen ailenin bir başka üyesi de Lala Mustafa Paşa'dır. Ağabeyi Hüsrev Paşa vasıtasıyla hizmete alınan Mustafa Paşa, şehzadeler arasındaki mücadelede kritik bir rol oynayarak Selim'in Bayezid'i saf dış1 etmesini sağlamış ve tahta giden yolu açmıştır. Rüstem Paşa'nın kendisini rakip olarak görmesiyle Şehzade Selim'den uzaklaştırılan Mustafa Paşa Erzurum, Haleb, Şam gibi eyaletleri idare etmiş, şöhretini ise Kıbrıs'ın fethiyle kazanmıştır. II. Selim'e olan yakınlığına rağmen Sokollu Mehmed Paşa'nın varlığı nedeniyle çok istediği sadrazamlığı elde edemeyen Mustafa Paşa, III. Murad devrinde de bu muradına erişememiş ve Sokollu Mehmed Paşa'nın öldürülmesinden bir yıl sonra hayatını kaybetmiştir. Mustafa Paşa'nın oğlu Mehmed Paşa ise birkaç sancakbeyliğinin ardından Zulkadriye ve Haleb beylerbeyliği yapmış, henüz otuz yaşındayken Haleb'de vefat etmiştir.

Sokoloviç ailesi mensuplarından Mustafa Paşa ve Ferhad Paşa özellikle Bosna ve Macaristan'daki hizmetleriyle dikkat çekmektedir. Mehmed Paşa'nın amcazadesi olarak İstanbul'a gelen ve saraydan çıktıktan sonra Fülek ve Klis ve Segedin sancaklarını yöneten Mustafa Paşa, Sigetvar seferi sırasında Budin beylerbeyi Arslan Paşa'nın saf dışı bırakılmasıyla Budin beylerbeyi olarak tayin edilmiştir. Mustafa Paşa'nın bu görevi elde etmesinde Sokollu Mehmed Paşa'nın da büyük rolü bulunmaktadır. Budin'de uzun bir süre görev yapan ve buranın bir Osmanlı şehri hüviyetine bürünmesi için önemli yapılar meydana getiren Mustafa Paşa, Sokollu Mehmed Paşa'nın gözden çıkarılmasının da tesiriyle 1579 yılında bir bahaneyle suçlu bulunarak öldürülmüştür. Ferhad Paşa da Mustafa Paşa gibi Klis sancakbeyliği yapmış, özellikle Venedik'e karşı sınırda faaliyetlerde bulunmuştur. Bir süre sonra Bosna beylerbeyi olan Ferhad Paşa daha sonra Budin beylerbeyi olmuş ve bu görevdeyken askerlerin isyanı neticesinde öldürülmüştür. 
Sokollu Mehmed Paşa'nın oğlu Hasan Paşa ise Bosna, Haleb, Diyarbekir, Şam beylerbeyliklerinden sonra özellikle Avusturya ile olan uzun savaş dönemindeki gayretleriyle dikkat çekmektedir. 1593 yılından 1598 yılına kadar Avusturya cephesinde bulunan Hasan Paşa, bu dönemde III. Mehmed tarafından Bağdad'a gönderilmiş, Anadolu'da baş gösteren Celali asilerini kontrol altına almak isterken Tokat'ta şehit düşmüştür. Mehmed Paşa'nın bir diğer oğlu Kurd ya da Kasım ise Budin valiliği yapmış ancak hakkındaki şikayetlerin fazlalığı nedeniyle babasının hayatında idam edilmiştir. Mehmed Paşa'nın İsmihan Sultan'dan olan oğlu İbrahim Han ise uzun süre kapıcıbaşı olarak görev yapmış, 1610 yılında Bosna beylerbeyi olmuştur. Daha sonra Rumili ve Hersek'i idare eden İbrahim Han 1622 yılında vefat etmiştir. Sokollu Mehmed Paşa'nın soyu İbrahim Han'dan devam etmiş, arşiv belgelerinden anlaşıldığı kadarıyla sonraki nesiller Sokollu ailesi vakıflarının idaresiyle ilgilenmişlerdir.

Sokoloviç ailesinden sadrazamlığa kadar yükselmeyi başaran ikinci kişi Lala Mehmed Paşa olmuştur. Sarayda çıktıktan sonra yeniçeri ağası olan, ardından Karaman ve Anadolu beylerbeyliği yapan Mehmed Paşa 1598'de Rumili beylerbeyi olmuş ve Avusturya savaşında önemli hizmetlerde bulunmuştur. I. Ahmed'in tahta geçmesinden bir süre sonra sadrazamllğa getirilen Mehmed Paşa 1606 yilında vefat etmiştir.

Kroniklerde ismi geçen diğer aile üyeleri ise Ferhad Paşa'nın kardeşleri Derviş Paşa ile Kara Ali Bey'dir. Şam, Haleb ve Diyarbekir beylerbeyliklerini idare ettiği kaydedilen Derviş Paşa'yla ilgili bilgiler cömertliğine dair övgülerle sınırlı kalmıştır. Kara Ali Bey ise uzun süre Macaristan'da görev yapmış ve 1595'te Avusturya'nın kuşattığı Estergon'da şehit düşmüştür.

$\mathrm{Bu}$ çalışma, Sokoloviç ailesi üyelerinin tam bir biyografisini inşa etme iddiası taşımamakla birlikte, aile üyeleri ile ilgili, yaşadıkları dönemlerin ana kaynakları sayılabilecek kroniklerde yer alan bilgilerin derlenmesini amaçlamıştır. Elbette kroniklerde aile üyelerinin tam bir listesini çıkarmak mümkün değildir. Sokoloviç ailesinin tam bir biyografisini yazmak, arşiv belgeleriyle desteklenecek çok daha kapsamlı bir çalışma ile ortaya konulabilecektir.

\section{Yazarın Notu}

Bu çalışma, 14-15 Ekim 2016'da Saraybosna/Bosna-Hersek'te düzenlenen "Mehmed-paša Sokolović (Sokollu Mehmed Pasha) and the Sokolović Family Throughout History" Uluslararas1 Sempozyumunda "Osmanlı Kroniklerinde Sokollu Mehmed Paşa ve Ailesi”" başlığı ile sunulan sözlü bildirinin genişletilmiş şeklidir.

\section{BİBLİYOGRAFYA}

Abdurrahman Şeref 1330, "Sokollu Mehmed Paşa'nın Evail-i Ahvali ve Ailesi Hakkında Bazı MalumatCevahirü'l-Menakıb”. Tarih-i Osmani Encümeni Mecmuası V/29, 257-265.

Abdülkadir Efendi 2003, Topçular Katibi Abdülkadir (Kadri) Efendi Tarihi (Metin ve Tahlil). Haz. Ziya Y1lmazer, Ankara.

Afyoncu E. 2009a, "Sokullu Mehmed Paşa". Türkiye Diyanet Vakfi İslam Ansiklopedisi 37, 354-357. İstanbul.

Afyoncu E. 2009b, "Sokulluzâde Hasan Paşa". Türkiye Diyanet Vakfi Íslam Ansiklopedisi 37, 366-368. İstanbul. Ahmed Cevdet Paşa 2018, Tarih-i Cevdet I. Haz. Mehmet İpşirli, Ankara.

Ahmed Refik 2017, Sokollu Mehmed Paşa. Haz. Yılmaz Kurt, Ankara.

Ak M. 2003, "Lala Mehmed Paşa". Türkiye Diyanet Vakfi İslam Ansiklopedisi 27, 71-73. İstanbul.

Altaylı Y. 2006, "Budin Beylerbeyi Arslan Paşa (1565-1566)”. OTAM XIX, 33-51.

Aykut N. 1997, "Hasanbeyzâde Ahmed Paşa". Türkiye Diyanet Vakfi İslam Ansiklopedisi 16, 363-364. İstanbul.

Babinger F. 1992, Osmanlı Tarih Yazarları ve Eserleri. Çev. Coşkun Üçok, Ankara.

Baysun M. Cavid 1953, "Hasan-Beyzade Ahmed Paşa". Türkiyat Mecmuası X, 321-340.

Celalzade Mustafa Çelebi 2011, Kanuni'nin Tarihçisinden Muhteşem Çağ: Tabakatü'l-Memalik ve Derecatü'lMesalik. Haz. Ayhan Yılmaz, İstanbul. 
Doğan G. 2017, “Venediklü ile dahi sulh oluna”: 17. ve 18. Yüzyıllarda Osmanl-Venedik İlişkileri. İstanbul.

Emecen F. 2000, “İbrahim Han”. Türkiye Diyanet Vakfi İslam Ansiklopedisi 21, 316-317. İstanbul.

Emecen F. 2002, "Osmanlı Hanedanına Alternatif Arayışlar: İbrahimhanzadeler Örneği”. XIII. Türk Tarih Kongresi Kongreye Sunulan Bildiriler III. Cilt III. Kısım. Ankara 4-8 Ekim 1999. Ankara, 1877-1886.

Emecen F. 2013, “Doğu Akdeniz'de Osmanlı Stratejisi: Sokullu Mehmed Paşa ve Kıbrıs". Eds. Halit Eren, Akdeniz'de İslam Medeniyeti Milletlerarası Konferans Tebliğleri. Lefkoşa 1-4 Aralık 2010. İstanbul, 177-183.

Evliya Çelebi 1999, Seyahatname. Haz. Seyit Ali Kahraman-Yücel Dağlı, İstanbul.

Feridun Ahmed Bey 2012, Nüzhet-i Esrârü'l-Ahyâr der-Ahbâr-ı Sefer-i Sigetvar. Haz. H.Ahmet ArslantürkGünhan Börekçi, İstanbul.

Fleischer C. H. 1996, Tarihçi Mustafa Âli: Bir Osmanlı Aydın ve Bürokratı. Çev. Ayla Ortaç, İstanbul.

Gelibolulu Mustafa Âlî 2000, Künhü'l-Ahbar. Haz. Faris Çerçi, Kayseri.

Gelibolulu Mustafa Âlî 2009, Künhü'l-Ahbar 4. rükn: Osmanlı Tarihi I (Tıpkıbasım), Ankara.

Gelibolulu Mustafa Âlî 2014, Nusret-nâme. Haz. Mustafa Eravcı, Ankara.

Gelibolulu Mustafa Âlî 2015, Nushatü's-selatin-Siyaset Sanatı. Haz. Faris Çerçi, İstanbul.

Gökbilgin T. 1979a, "Mehmed Paşa, Sokollu”. İslam Ansiklopedisi 8, 595-605. İstanbul.

Gökbilgin T. 1979b, "Hasan Paşa, Sokulluzade”. İslam Ansiklopedisi 5/1, 325-329. İstanbul.

Gökbilgin T. 1979c, "İbrahim Han”. İslam Ansiklopedisi 5/2, 894-896. İstanbul.

Hammer J. 1332, Devlet-i Osmaniye Tarihi. Çev. Mehmed Ata, İstanbul.

Hancz E. 2007, "Peçuylu İbrâhim”. Türkiye Diyanet Vakfi İslam Ansiklopedisi 34, 216-218. İstanbul.

Hasan Bey-zade Ahmed Paşa 2004, Hasan Bey-zade Tarihi. Haz. Şevki Nezihi Aykut, Ankara.

İpşirli M. 2001, "Kadızade, Ahmed Şemseddin”. Türkiye Diyanet Vakfi İslam Ansiklopedisi 24, 96-97. İstanbul. İsen M. 1988, Gelibolulu Mustafa Âlî. Ankara.

Jorga N. 2005, Osmanlı Imparatorluğu Tarihi III. Çev. Nilüfer Epçeli, İstanbul.

Kaçan Erdoğan M. 2016, “Budin Beylerbeyi Sokullu Mustafa Paşa'nın Macaristan'daki Hayratı”. Türk Kültürü Incelemeleri Dergisi 35, 67-116.

Kaldy-Nagy G. 1990, "Budin Beylerbeyi Mustafa Paşa (1566-1578)”. Belleten LIV/210, 649-663.

Katip Çelebi 2016, Fezleke. Haz. Zeynep Aycibin, İstanbul.

Koric E. 2015, Životni put prvog beglerbega Bosne: Ferhad-paša Sokolović (1530-1590). Sarajevo.

Koyuncu A. 2015, "Devşirme Tarihine Bir Derkenar: Bosna'nın İslamlaşması ve Osmanlı Terminolojisinde Potur ve Potur Oğulları Terimlerinin Anlamı”. Eds. Yunus Koç-Serhat Küçük, Türk Sosyal Tarihçiliğinde Bir Yalnız İsim: Bahaeddin Yediyıldız'a Armağan. Ankara, 213-259.

Kütükoğlu B. 1979, “Mustafa Paşa, Lala, Kara”. İslam Ansiklopedisi 8, 732-736. İstanbul.

Kütükoğlu B. 1989, “Âlî Mustafa Efendi”. Türkiye Diyanet Vakfi İslam Ansiklopedisi 2, 414-416. İstanbul.

Lamartine A. 2008, Osmanlı Tarihi. Çev. Serhat Bayram, İstanbul.

Lütfi Paşa 1341, Tevarih-i Al-i Osman. İstanbul.

Mehmed Süreyya 1999, Sicill-i Osmani. Haz. Nuri Akbayar, İstanbul.

Muvakkit Salih Sıdkı Efendi ?, Tarih-i Bosna ve Hersek I. Gazi Husrev Beg Kütüphanesi İslâmi Yazmalar Katalogu, n. 7551.

Nahîfî Mehmed Efendi 2019, Cevâhiru'l-menâkıb. Haz. İbrahim Pazan, İstanbul.

Naîmâ Mustafa Efendi 2007, Târih-i Na îmâ. Haz. Mehmet İpşirli, Ankara.

Nasûhü’s-Silâhî (Matrakçı) 1976, Beyan-ı Menazil-i Sefer-i Irakeyn-i Sultan Süleyman Han. Haz. Hüseyin Yurdaydın, Ankara.

Oruç H. 2005, “15. Yüzyılda Bosna Sancağı ve İdari Dağılımı”. OTAM 18, 249-271.

OTAM Osmanlı Tarihi Araştırma ve Uygulama Merkezi Dergisi.

Özcan A. 1999, "Hüsrev Paşa, Deli”. Türkiye Diyanet Vakfi İslam Ansiklopedisi 19, 40-41. İstanbul.

Özcan A. 2017, Fatih Sultan Mehmed-Atam Dedem Kanunu: Kanunnâme-i Âl-i Osman. İstanbul.

Peçevî İbrahim Efendi 1866, Tarih-i Peçevî. cilt I-II, İstanbul.

Samarcic R. 1995, Dünyayı Avuçlarında Tutan Adam: Sokollu Mehmed Paşa. Çev. Meral Gaspıralı, İstanbul.

Selanikî Mustafa Efendi 1999, Tarih-i Selanikî. Haz. Mehmet İpşirli, Ankara.

Tekindağ Ş. 1979, “Mehmed Paşa, Lala”. İslam Ansiklopedisi 7, 591-595. İstanbul.

Turan Ş. 1958, "Lala Mustafa Paşa Hakkında Notlar ve Vesikalar". Belleten XXII/88, 551-593.

Turan Ş. 1964, "Peçevî”. İslam Ansiklopedisi 9, 543-545. İstanbul.

Turan Ş. 2011, Kanuni Sultan Süleyman Dönemi Taht Kavgalart. İstanbul.

Uzunçarşılı İ.H. 1988, Çandarlı Vezir Ailesi. Ankara.

Uzunçarşı1ı İ.H. 2011, Osmanlı Tarihi II. Ankara.

Yıldız M. 2014, "Havsa'daki Şehit Mehmed Paşazade Kasım Paşa Vakfi”. Vakıflar Dergisi 41, 97-114.

Yücel Y. 1988, Osmanlı Devlet Teşkilatına Dair Kaynaklar: Kitab-ı Müstetab, Kitabu Mesâlihi'l-Müslimîn ve Menâfi'i'l-Mü'minîn, Hırzü'l-Mülûk. Ankara.

Zinkeisen J.W. 2011, Osmanlı İmparatorluğu Tarihi III. Çev. Nilüfer Epçeli, İstanbul. 